\title{
ГИГАНТСКИЕ ГАЗО-ГИДРОТЕРМАЛЬНЫЕ СИСТЕМЫ И ИХ РОЛЬ В ФОРМИРОВАНИИ ПАРОДОМИНИРУЮЩИХ ГЕОТЕРМАЛЬНЫХ МЕСТОРОЖДЕНИЙ И РУДНОЙ МИНЕРАЛИЗАЦИИ
}

\author{
(C) 2014 г. С. Н. Рычагов \\ Институт вулканологии и сейсмологии ДВО РАН \\ 683006 Петропавловск-Камчатский, бульвар Пийпа, 9, \\ e-mail:rychsn@kscnet.ru \\ Поступила в редакцию 21.01.2013 г.
}

\begin{abstract}
Дана характеристика уникальных геологических структур Земли - гигантских газо-гидротермальных систем, в недрах которых на современном этапе развития формируются крупнейшие в мире пародоминирующие геотермальные месторождения. На основе обобщения литературных данных и материалов собственных исследований показано, что системы образуются в зонах глубинных разломов на сочленении океанических и континентальных плит, в структурах вулканических островных дуг, в областях тектоно-магматической активизации земной коры. Системы являются сквозькоровыми и обладают огромным геотермальным и рудным потенциалами. Установлено, что в этих системах восходящий высокотемпературный газо-водный флюид, а также все типы смешанных вод и минеральные новообразования в зоне гипергенеза геотермальных аномалий участвуют в процессах транспорта, накопления и перераспределения комплексных соединений многих металлов (Fe, $\mathrm{Al}, \mathrm{Ti}, \mathrm{Au}, \mathrm{Ag}, \mathrm{Hg}, \mathrm{As}, \mathrm{Sb}$, др.). Сделано заключение, что газо-гидротермальные системы и образующиеся в их недрах пародоминирующие геотермальные месторождения отражают условия зарождения мезо- и эпитермальных золото-полиметаллических и $\mathrm{Au}-\mathrm{Ag}-\mathrm{Cu}-\mathrm{Mo}-\ldots$. порфировых месторождений.
\end{abstract}

DOI: $10.7868 / \mathrm{S} 0203030614020060$

\section{ВВЕДЕНИЕ}

В областях современного и четвертичного вулканизма выделены крупные осесимметричные геологические структуры, характеризующиеся высокой насыщенностью вмещающих пород трещинно-поровыми растворами и перегретым (сухим) паро-газовым флюидом. Структуры расположены в зонах сочленения региональных тектонических блоков, в сквозькоровых разломах и, как правило, локализуются в центральных частях вулканогенно-рудных центров. Они контролируют современные газо-гидротермальные системы и крупнейшие пародоминирующие геотермальные месторождения (с энергетическим потенциалом $\geq 100$ МВт) [Bertani et al., 2005; Norton, Hulen, 2001; Rychagov, 2005]. К наиболее известным из таких систем относятся Гейзерс (США), Лардерелло-Травале (Италия), Какконде и Матсукава (Япония), Камоджанг и Дараджат (Индонезия), Кошелевская и, возможно, Северо-Парамуширская (Россия, Дальний Восток) [Белоусов и др., 2002; Поздеев, Нажалова, 2008; Bellani et al., 2004; Hanano, Sakagawa, 1990; Rejeki et al., 2010; Stimac et al., 2001]. Обычно эти системы рассматриваются только с позиции оценки геотермальных ресурсов. Но в последнее время показано, что в пределах таких структур создаются условия для образования золото-полиметаллических и редкометальных эпии мезотермальных месторождений и минерализации $\mathrm{Au}-\mathrm{Ag}-\mathrm{Cu}-\mathrm{Mo}-. .$. порфирового типа [Рычагов и др., 2002; Hedenquist et al., 1996]; имеются предпосылки для обнаружения нефтегазовых проявлений, а также разнообразных нерудных полезных ископаемых [Поздеев, Нажалова, 2008]. Ранее они были определены как длительноживущие сквозькоровые рудообразующие гидротермально-магматические системы, обладающие высоким геотермальным потенциалом [Рычагов, 2003]. Но наши более детальные исследования позволяют выделить определенный тип гидротермально-магматических систем - газо-гидротермальные в связи с особой ролью газов различного состава в транспорте теплоносителя и химических соединений. В настоящей статье рассматриваются газо-гидротермальные системы, на современном этапе развития которых образуются крупнейшие в мире пародоминирующие геотермальные месторождения. Таким образом, задача настоящей работы состояла в изучении особенностей строения и получении основных общих характеристик этих уникальных геологических структур Земли для оценки их роли в генерации и транспорте тепловой энергии и глубинных рудообразующих флюидов. 


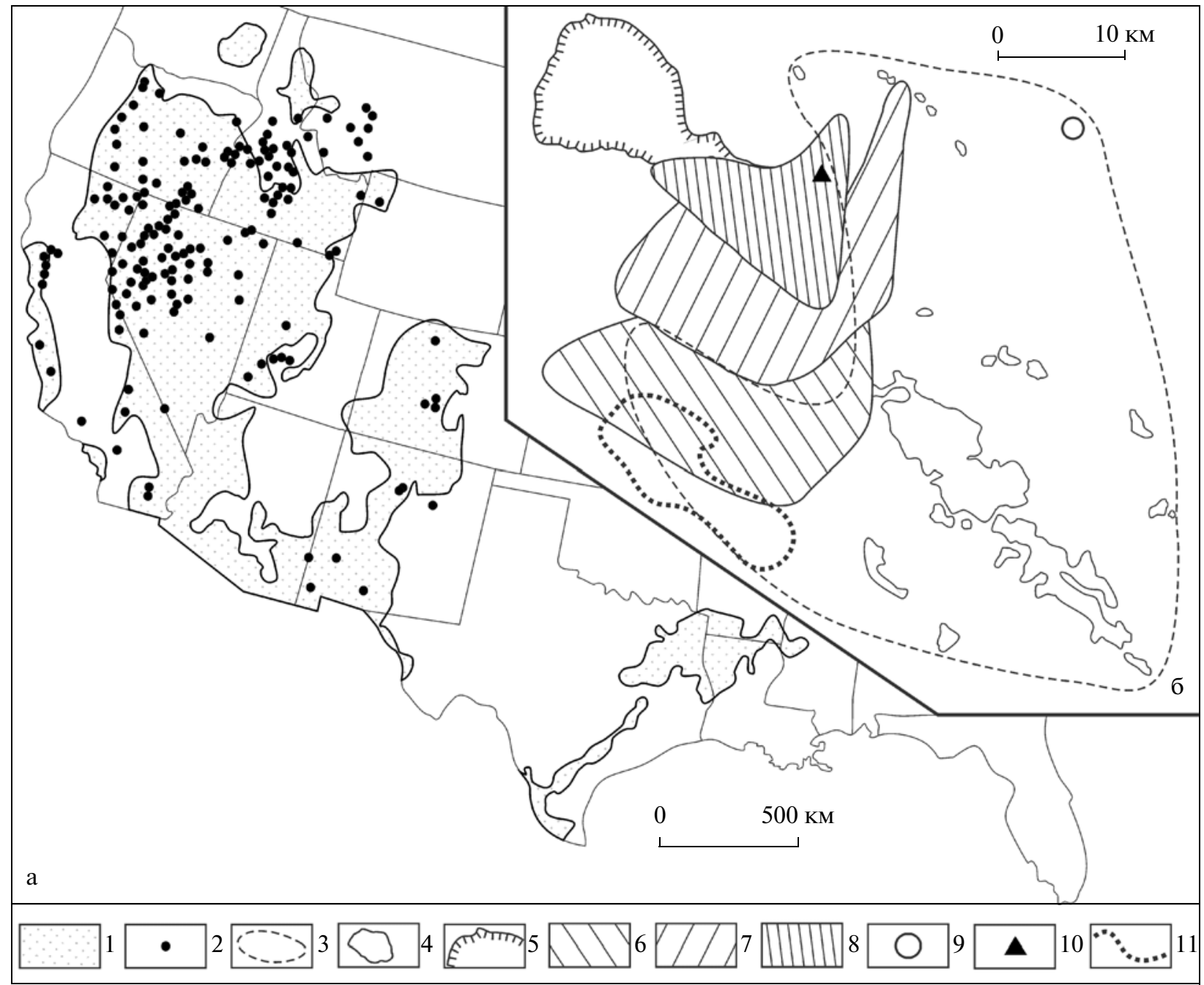

Рис. 1. Геотермальные районы и современные гидротермальные системы США [Stimac et al., 2001]. a - карта теплового поля западной части США, б - геотермальный район Гейзерс - Ясное Озеро.

1 - территории, отличающиеся аномально высоким кондуктивным и конвективным тепловыми потоками; 2 - высокотемпературные $\left(\geq 150^{\circ} \mathrm{C}\right)$ гидротермальные системы; 3 - граница поля вулканических пород, имеющих возраст $1.3-$ 2.1 млн лет; 4 - поля развития пород вулкана Ясное Озеро; 5 - кальдера вулкана Ясное Озеро; 6-8 - поля вулканитов, имеющих возраст 0.8-1.2 млн лет (6), 0.3-0.6 млн лет (7) и 0.01-0.2 млн лет (8); 9 - гидротермальная система Вилбур Спрингс; 10 - рудник Сульфур Бэнк; 11 - границы геотермальной системы Гейзерс.

\section{ХАРАКТЕРИСТИКА ГИГАНТСКИХ \\ ГАЗО-ГИДРОТЕРМАЛЬНЫХ СИСТЕМ И КРУПНЕЙШИХ ПАРОДОМИНИРУЮЩИХ МЕСТОРОЖДЕНИЙ МИРА}

Гейзерс (США). Газо-гидротермальная система Гейзерс и одноименное пародоминирующее геотермальное месторождение расположены в штате Калифорния (рис. 1). На северо-западе США сосредоточены основные геотермальные ресурсы страны, обусловленные высокими кондуктивным и конвективным тепловыми потоками и наличием большого числа современных высокотемпературных гидротермальных систем. Территория штата Калифорния характеризуется максимальной мощностью теплового потока в этом регионе и наибольшими температурными градиентами [Lachenbruch, Sass, 1980], что связано с наложением конвективной зоны на высокотемпературную кондуктивную тепловую аномалию. Считается, что повышенный конвективный тепловой поток определяется близповерхностными остывающими кислыми интрузиями. Кровля интрузий располагается на глубинах 3-4 км, корневые зоны погружаются в горячие $\left(>700^{\circ} \mathrm{C}\right)$ интрузивные породы основного состава, расположенные на глубине более 8 км [Walters, Combs, 1989].

Геотермальный район, в состав которого входит система Гейзерс и вулканическое поле Ясное Озеро (см. рис. 1), приурочен к серии разломов, оперяющих трансатлантический разлом Сан-Ан- 
дреас на участке сочленения трех плит: Тихоокеанской, Североамериканской и плиты Горда. Это так называемое Тройное Сочленение Мендосино [Castillo, Ellsworth, 1993; Jennings, 1992]. Региональный тектонический анализ и возрастная корреляция между вулканизмом Берегового хребта и Тройным Сочленением Мендосино привели к выводу о том, что магматизм в регионе обусловлен мантийным апвеллингом в южной оконечности плиты Горда [Benz et al., 1992; Dickinson, Sny$\mathrm{der}, 1979]$. Предполагается, что, начиная с нижнего миоцена, вулканические поля периодически формировались над мигрирующим окном в тектонической плите над астеносферой. Разлом СанАндреас на широте вулканического поля Ясное Озеро асейсмичен, здесь преобладает режим растяжения, что привело к внедрению крупных гранитоидных интрузий в верхние горизонты земной коры и формированию геотермальной аномалии.

Вулканизм геотермального района развивался от плейстоцена (образование кальдеры и вулканических полей Ясное Озеро) до голоцена (лавоэксплозивная деятельность в северной части района). Малообъемные излияния лав андезибазальтов менялись на крупнообъемные извержения кислых расплавов, которые обычно начинались с высокотемпературных афировых риолитов и постепенно сменялись более раскристаллизованными риолитовыми и дацитовыми лавами [Stimac, 1991]. В районе выделяется несколько современных гидротермальных систем. К голоценовым вулканитам на севере района приурочена система преимущественно водного типа (температура растворов на глубине $1.0-1.5$ км составляет $210-220^{\circ} \mathrm{C}$ ) и рудник Сульфур Бэнк - одно из крупнейших в мире месторождений ртути с попутной добычей бора и серы (начало эксплуатации рудника относится к 1856 г., завершение - к 1957 г.). В северо-восточной части вулканического поля находится низкотемпературная $\left(<140^{\circ} \mathrm{C}\right)$ вододоминирующая система Вилбур Спрингс. Знаменитая газо-гидротермальная система Гейзерс и крупнейшее в мире пародоминирующее геотермальное месторождение расположены в поле среднечетвертичных вулканитов преимущественно кислого состава.

На основании химических, петрологических и изотопно-геохимических данных установлено, что большая часть мафических лав является в разной степени контаминированными коровыми расплавами, включающими обломки кристаллических пород [Futa et al., 1981; Stimac, 1993]. Kceнолиты представлены норитовыми и габброидными плутоническими и высокометаморфизованными породами: фрагментами габбровых интрузий и пород их контактовых ореолов. Р-Т-условия формирования пород ксенолитов (780-900 $\mathrm{C}$ и 4-6 кбар) свидетельствуют о том, что часть мафической магматической системы располагается в средней земной коре (12-18 км). Выделяются два уров- ня магматической системы (рис. 2). Глубинная часть представлена мафическими интрузиями, метаморфитами гранулитовых фаций и локальными выплавками метаосадочных протолитов, постепенно сменяющимися контаминированными и гибридизированными магмами среднего и кислого состава, образующими крупный неоднородный магматический очаг на глубинах от 4-5 до 11-12 км [Stimac et al., 2001]. Этот очаг продуцировал андезибазальтовые и риолитовые лавы. По меньшей мере один такой плутонический комплекс кислого состава вскрыт глубокими скважинами в районе геотермальной системы Гейзерс. Комплекс представлен гранит-порфирами и фельзитами в краевых частях плутона.

Гейзерс является крупнейшей газо-гидротермальной системой мира. Установленная мощность ГеоЭС, базирующаяся на эксплуатации одноименного пародоминирующего геотермального месторождения, составила $1522 \mathrm{MBт}_{э}$ (в целом по США мощность всех ГеоЭС оценивается в $3093 \mathrm{MBT}_{\ni}$ ), производство геотермальной электрической энергии в 2010 г. было на уровне 8000 ГВт/ч (аналогичный показатель в целом для США 16600 ГВт/ч) [Lund et al., 2010]. Система является также одним из наиболее изученных участков земной коры: здесь пробурено 780 скважин, в т.ч. глубиной до 4 км и более. Скважинами вскрыта длительноживущая гидротермальная система, приуроченная к апикальным частям плутонического комплекса гранит-порфиров и фельзитов (см. рис. 2). Система имеет трехъярусное строение. Нижняя, преимущественно жидкостная, палеогидротермальная система, согласно K/Ar и Ar/Ar датированию кварцадуляровых жил, имеет возраст 0.7-0.25 млн лет [McLaughlin et al., 1983] и локализована не только в кровле фельзитового тела, но и вокруг гранит-порфиров. Она выделяется широким развитием вторичных кварцитов и кварц-адуляровых жил. На основании изучения газово-жидких включений температура растворов составляла от $450^{\circ} \mathrm{C}$ непосредственно у границ плутонов, до $330^{\circ} \mathrm{C}$ на удалении 1.4 км от интрузии [Moore, Gunderson, 1995]. Флюидные включения содержат концентрированный рассол (до 44 вес. \% $\mathrm{NaCl}$ экв.). Считается, что более молодые флюидные включения слабо минерализованы и представлены конденсатом пара или гидротермами, смешанными с метеорными водами [Moore et al., 2000]. Современная система вододоминирующего типа локализуется в проницаемых раздробленных хрупких метаморфических породах (метаграувакках, аргиллитах, метабазальтах) в области, повторяющей конфигурацию эндо-экзоконтактовой зоны фельзитов. Температура растворов соответствует $320-230^{\circ} \mathrm{C}$. Для этого этапа характерно образование кальцитовых жил с сульфидными минералами, а также сульфидной минерализации в виде тонкой рассеянной вкрапленности во вме- 


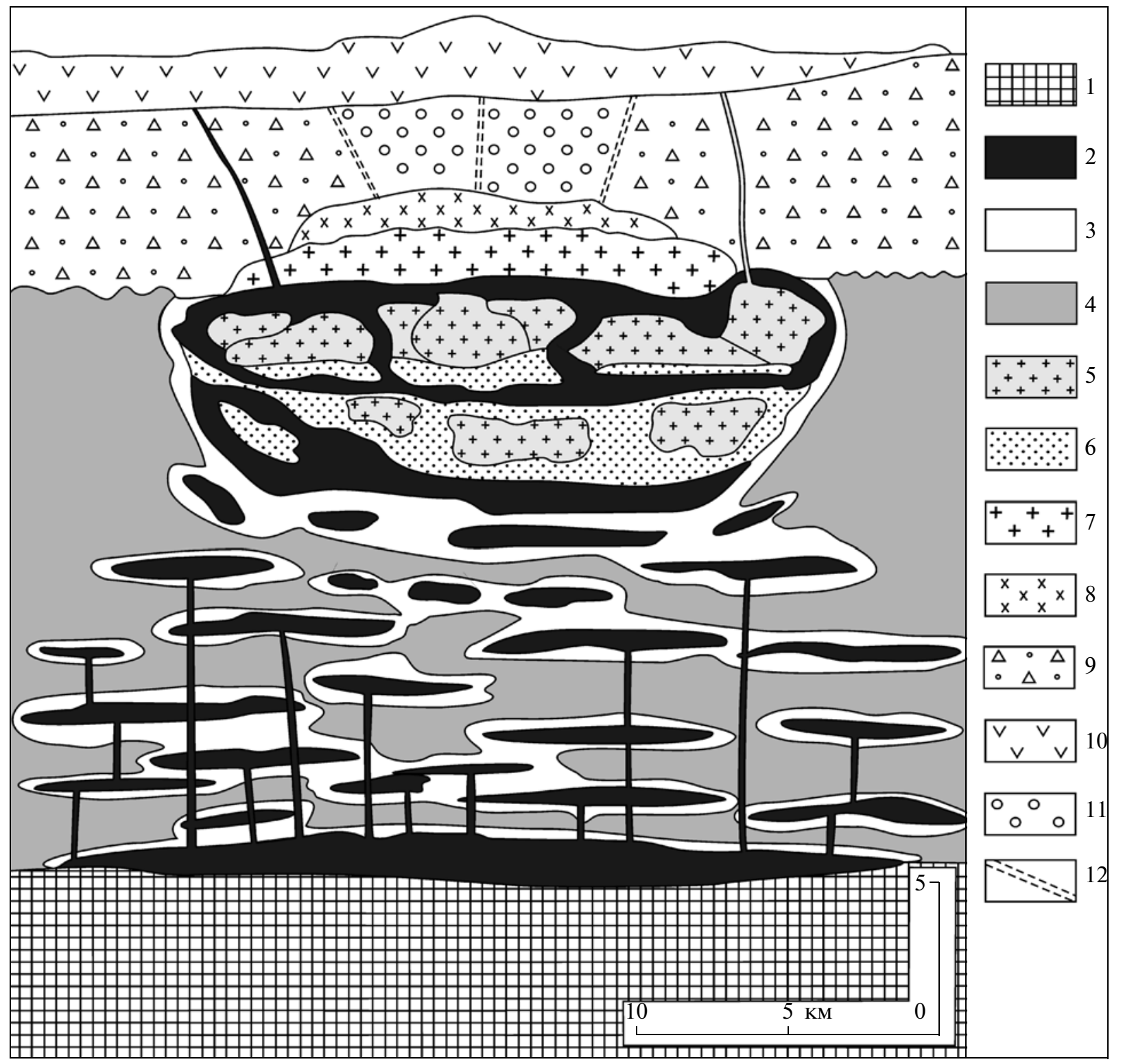

Рис. 2. Концептуальный разрез гидротермально-магматической системы Гейзерс [Stimac et al., 2001] с изменениями и дополнениями.

1 - кристаллические породы; 2 - габбровые кумуляты; 3 - расплавы кислого состава; 4 - вмещающая вулканогенноосадочная толща; 5-6 - неглубоко залегающая преимущественно кислая магматическая система: 5 - кислые дифференциаты, 6 - более основные расплавы; 7 - гранит-порфиры; 8 - фельзиты; 9 - вулканогенно-осадочная толща пород плиоцен-четвертичного возраста, вмещающая гидротермальную систему; 10 - лавы и туфы андезитов и дацитов возрастом от 2.1 млн лет до голоцена (см. рис. 1); 11 - пародоминирующая система Гейзерс; 12 - предполагаемые зоны тектонических нарушений в структуре гидротермальной системы.

щающих метаморфизованных породах. Данная часть системы подстилает пародоминирующую область, которая в свою очередь имеет двухъярусное строение. Верхний (“нормальный”) резервуap, занимающий большую часть системы, имеет температуру около $240^{\circ} \mathrm{C}$ и давление 35 бар. Он подстилается высокотемпературным резервуаром $\left(300-340^{\circ} \mathrm{C}\right)$, характеризующимся давлением пара, соответствующим режиму вышерасположенной зоны кипения [Walters et al., 1992]. "Нормаль- ный” резервуар представляется в виде тепловой трубы, где энергия передается вверх паро-газовой смесью, жидкая фаза плотно сжата за счет адсорбции и капиллярных сил в микротрещинках пород, а конденсат пара инфильтруется в виде гидротерм на более глубокие горизонты гидротермальной системы [Pruess, 1985]. В геотермальном районе Гейзерс и плейстоцен-голоценовых вулканитах Ясное Озеро находится большое количество источников, фумарол и газовых струй, выде- 
ляющих в атмосферу огромное количество $\mathrm{CO}_{2}$, а также $\mathrm{CH}_{4}$ [Bergfeld et al., 1997]. Изотопно-геохимические исследования показали, что углерод углекислого газа и метана может иметь несколько источников происхождения: поступает в систему в результате растворения кальцитовых жил и морских карбонатных пород, разложения органических остатков и вследствие магматической дегазации [Bergfeld et al., 2001]. Растворение кальцита перегретым паром и дегазация гранит-порфировых интрузий связаны непосредственно с эволюцией газо-гидротермальной системы.

Таким образом, газо-гидротермальная система Гейзерс отражает новейший этап развития длительноживущей (по меньшей мере с верхнего миоцена по голоцен) сквозькоровой гидротермальномагматической системы, локализованной в пределах вулканического центра Ясное Озеро на участке сочленения океанических (Тихоокеанской и Горда) и континентальной (Североамериканской) тектонических плит. На примере газо-гидротермальной системы Гейзерс установлена прямая связь между конвективной гидротермальной ячейкой и магматическим источником теплового и флюидного питания (гранитоидными интрузиями). Эволюция системы в течение 700 тыс. лет заключалась в смене высокотемпературного (450$330^{\circ} \mathrm{C}$ ) вододоминирующего режима на более низкотемпературный $\left(320-230^{\circ} \mathrm{C}\right)$ также существенно водный и в последующем на пародоминирующий режим на современном этапе. Большую роль в переносе тепла и транспорте гидротермальных флюидов играют углекислый газ и метан, генерация которых происходит на глубоких уровнях. Этапы развития системы с преобладанием вододоминирующего режима характеризуются образованием сульфидной минерализации, ассоциирующей с кварц-адуляровыми и кальцитовыми жилами; с преобладанием пародоминирующего режима - более сложной и менее изученной рудной минерализации в виде рассеянной тонкой вкрапленности пирита и других сульфидов (а также, возможно, самородных металлов и интерметаллических соединений) в кислых пропилитизированных четвертичных вулканитах. Как было показано нами ранее, мощные зоны кипения гидротерм выделяются сложной рудной минеральной зональностью и образованием самородных металлов и интерметаллических соединений, выполняющих поры и микротрещинки в окварцованных породах [Рычагов и др., 1996; Рычагов и др., 2002].

Лардерелло-Травале (Италия). Газо-гидротермальная система Лардерелло-Травале расположена в зоне коллизии на границе Адриатической и Европейской тектонических плит и приурочена к северному сектору Террейн-Апеннинской тектонической структуры [Verdoya et al., 2005]. Выделя- ется три, коротких по продолжительности, этапа тектоно-термальной эволюции этой структуры: древний (Восточно-Корсиканский) 14 млн лет назад, средний (Каприа-Эльба) 7 млн лет, молодой (Восточная Эльба) 3 млн лет. С последней зоной молодого рифтогенеза связано образование обширных полей неоген-четвертичных вулканитов, источником которых служат верхнекоровые дифференцированные магматические очаги; а также образование отдельных центров вулканитов неоген-четвертичного возраста, развивающихся над верхнекоровыми очагами гибридизированных магм.

Эволюция магматических очагов обоих типов определила историю развития геотермальных районов Северных Апеннин: Лардерелло-Травале и Монте-Амиата (рис. 3). Лардерелло-Травале является крупнейшим геотермальным районом и газо-гидротермальной системой Северных Апеннин. Глубокими (до 4.5 км) скважинами вскрыты изверженные, осадочные и метаморфические породы. Под юрскими и кайнозойскими офиолитами и флишевыми толщами Тосканского надвига выделяется зона тектонических чешуй (“срезанных блоков”), вовлекавших в субгоризонтальные тектонические деформации мезозойские породы [Pandeli et al., 1994]. Метаморфические породы представлены гранатовыми слюдистыми сланцами и гнейсами [Gianelli et al., 1978], интрузии гранитами и гранит-порфирами, возраст которых определен в интервале 3.8-1.6 млн лет [Villa, Puxed$\mathrm{du}, 1994]$. На основании сейсмологических данных показано, что мелкие тела гранитов на глубине более 7-8 км объединяются в крупный батолит объемом примерно $2 \times 10^{4} \mathrm{kM}^{3}$ [Gianelli et al., 1997]. Минимальный объем подобного батолита на МонтеАмиата может достигать $5 \times 10^{3} \mathrm{KM}^{3}$ [Bernabini et al., 1995]. Для обоих районов характерны большие градиенты давлений, высокие температуры $\left(>420^{\circ} \mathrm{C}\right)$, подъем изотерм над отдельными (приподнятыми) блоками пород, наличие горячих рассолов в зоне хрупко-пластичных деформаций пород, присутствие на небольшой глубине (до нескольких километров) частично или полностью расплавленных пород. Такая геолого-геофизическая модель хорошо согласуется с геодинамикой внутренней части Северных Апеннин, характеризующихся подъемом астеносферного блока и уменьшением мощности Европейской плиты [Reutter et al., 1980; Suhadolc, Panza, 1988].

Геотермические исследования в районе Лардерелло-Травале были начаты в 1926 г. В карбонатэвапоритовых породах вскрыты два неглубоких продуктивных резервуара: в пределах горста на глубине 600-800 м разведан паровый резервуар, характеризующийся давлением около 6 МПа и температурой до $270^{\circ} \mathrm{C}$; в структуре грабена разбурен близкий по термодинамическим парамет- 


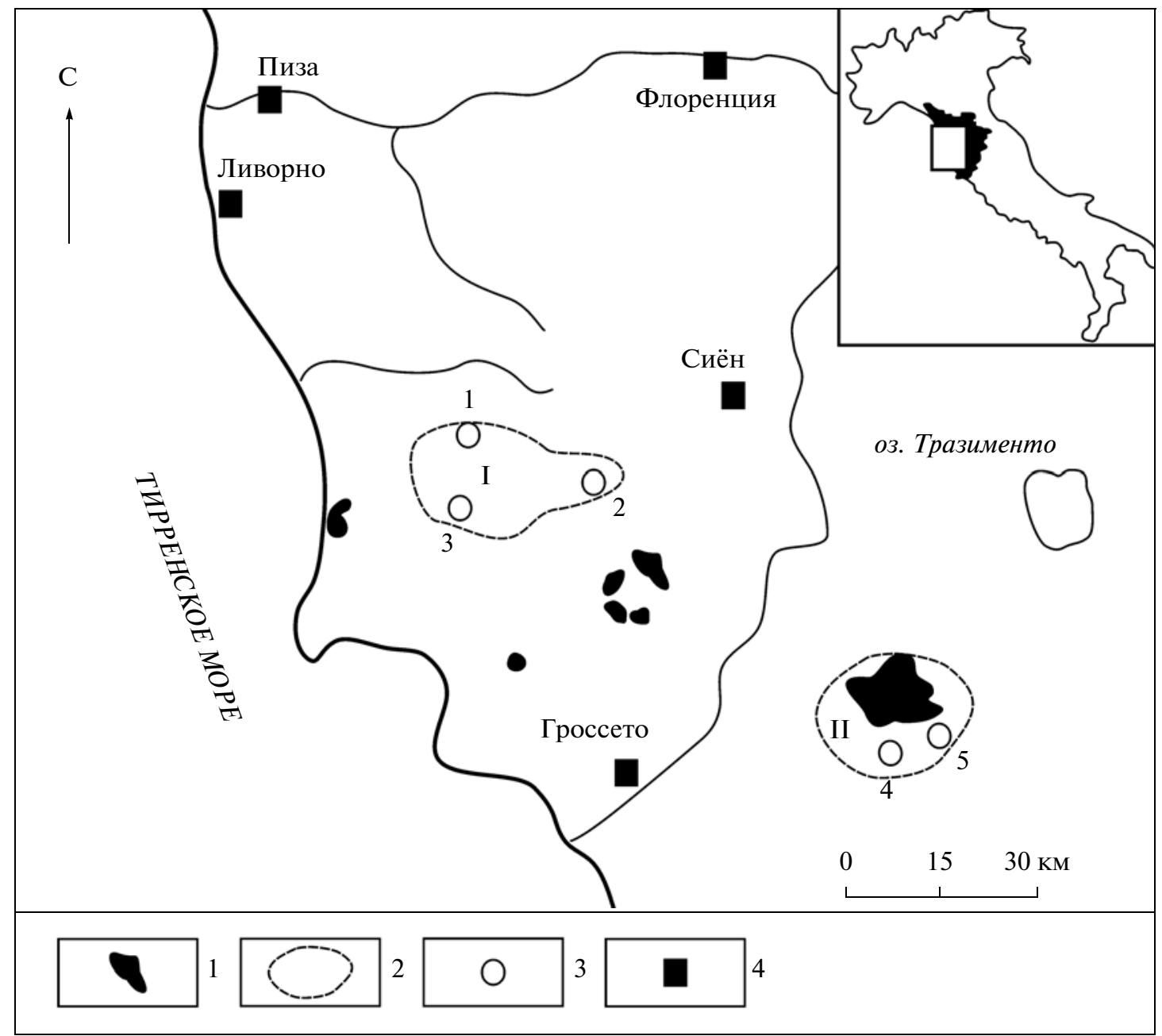

Рис. 3. Крупнейшие геотермальные районы Италии: Лардерелло-Травале (I) и Монте-Амиата (II) [Gianelli et al., 1997]. 1 - поля развития магматических пород; 2 - граница геотермальных районов; 3 - крупнейшие геотермальные месторождения: 1 - Лардерелло, 2 - Травале, 3 - Лагони Росси, 4 - Багноре, 5 - Пианкастагнио; 4 - основные населенные пункты.

рам паровый резервуар на глубинах 1300-2500 м. Интенсивная эксплуатация этих резервуаров, имеющих общую площадь $180 \mathrm{kM}^{2}$ и объем около $200 \mathrm{Kм}^{3}$, продолжалась до 1970-х годов. В результате последующего глубокого бурения доказано существование продуктивных горизонтов в метаморфическом фундаменте, подстилающим карбонатно-эвапоритовые породы [Bertani et al., 2005]. Нижний резервуар Лардерелло-Травале имеет температуру $300-350^{\circ} \mathrm{C}$, давление 4-7 МПа и представляет собой огромную глубинную (2.5-4.5 км) геотермальную систему площадью более $400 \mathrm{~km}^{2}$. На основании бурения скважин и микросейсмического зондирования выделены три мощные зоны повышенной трещиноватости и дробления пород: в кровле тектонического клина (основании толщи филлитов и блоков-пластин карбонатных пород), в кровле метаморфического фундамента в экзоконтактовых зонах крупных батолитов древ- них гранитов (горизонт “Н”), и на границе между молодыми и древними гранитами (горизонт "К”) (рис. 4). Горизонт “Н” представлен скарнами, роговиками, другими окремненными метаморфическими породами; связанная с этим горизонтом продуктивная зона характеризуется температурой от 300 до $350^{\circ} \mathrm{C}$ и давлением 5-5.5 МПа. Расход пара составляет 30 кг/с. Вероятно, горизонт "К”, выделенный по сейсмическим данным, отвечает геотермальному резервуару с надкритическими P-Т-параметрами флюида. В целом, газо-гидротермальная система Лардерелло-Травале имеет сложное многоярусное строение: в основании каждого яруса залегают перегретые термальные воды (вероятно, рассолы), расположенные выше трешиноватые и пористые породы насыщены паро-газовой фазой.

Механизм формирования крупных зон кипения гидротерм представляется следующим обра- 


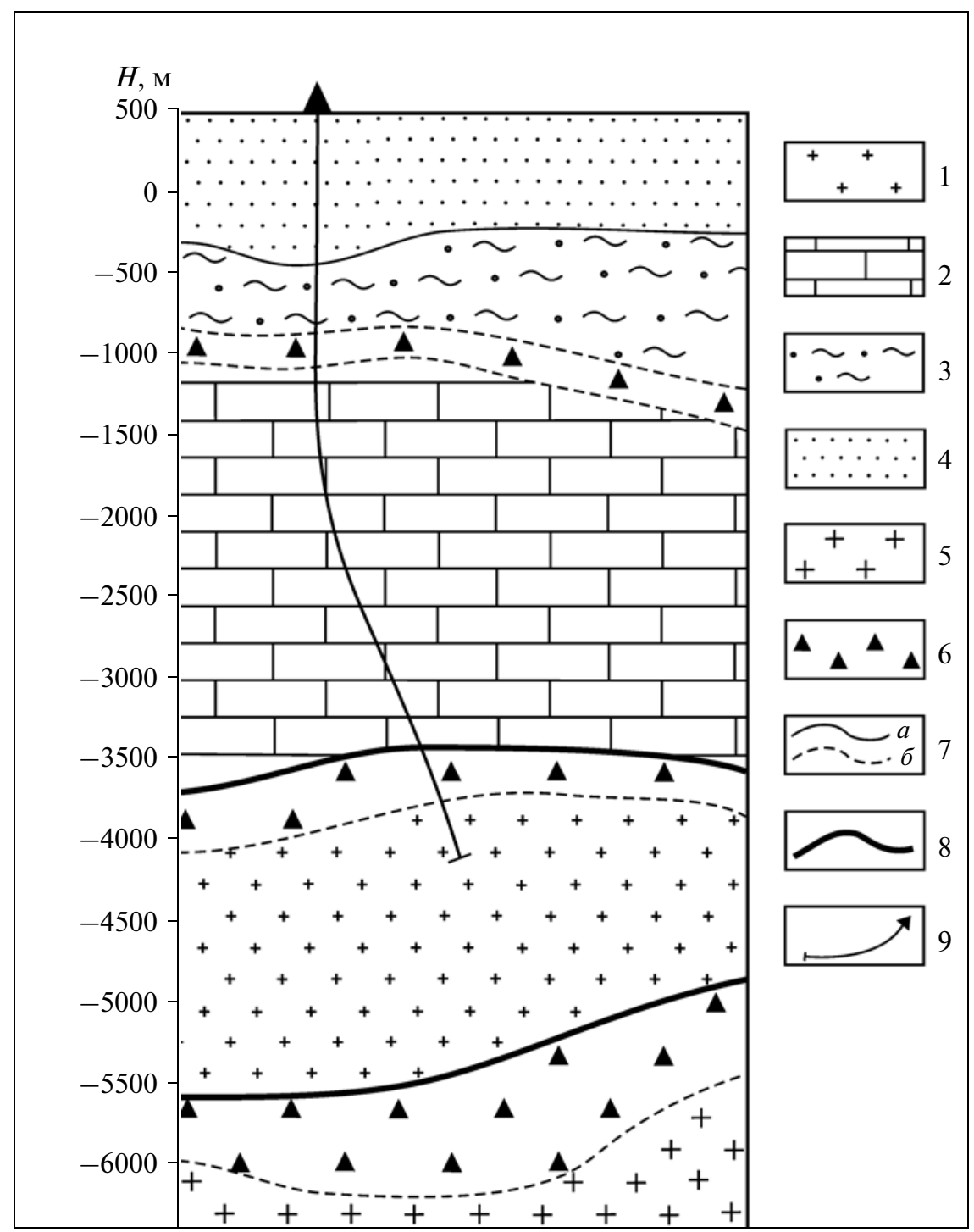

Рис. 4. Геологический разрез одного из наиболее изученных участков газо-гидротермальной системы Лардерелло-Травале [Bertani et al., 2005].

1 - метаморфический фундамент и древние граниты; 2 - карбонат-эвапоритовые отложения; 3 - филлиты; 4 - вулканогенно-осадочные отложения; 5 - молодые граниты; 6 - зоны повышенной трещиноватости и дробления пород (тектонические маркеры): нижняя - горизонт "К”, средняя - горизонт "Н", верхняя - без названия; 7 - границы: $a$ - литологическая, 6 - тектоническая; 8 - кровля горизонтов “Н” и “К”; 9 - скважина.

зом (рис. 5). Подъем молодых гранитов приводит к разрыву пород метаморфического фундамента и древних гранитов на приподнятые блоки, в кровле которых формируется неоднородная брекчиево-блоковая зона, проницаемая для газо-гидротермального флюида. Эта зона является в настоящее время доступным и наиболее продуктивным паро-газовым резервуаром с высокими Р-Т-параметрами теплоносителя $\left(\geq 350^{\circ} \mathrm{C}\right.$ и 5-7 МПа). Основание блоков, вероятно, может рассматриваться как область генерации глубинных высокотемпературных (перегретых) флюидов. Эксплуатируемые геотермальные месторождения Лардерелло, Травале и Лагони Росси и выделенные по данным буре- ния близповерхностные и глубинные геотермальные резервуары расположены над этими блоками. Аналогичная геолого-структурная позиция зон восходящего высокотемпературного потока гидротерм, локализация таких зон в структурах горстов или локальных приподнятых тектоно-магматических блоков показана нами на примере гидротермально-магматических систем Курило-Камчатской островной дуги [Рычагов, 1993; Структура..., 1993].

Таким образом, газо-гидротермальная система Лардерелло-Травале имеет магматический источник тепла и глубинных флюидов. Образована за счет внедрения гранитоидных интрузий во вме- 


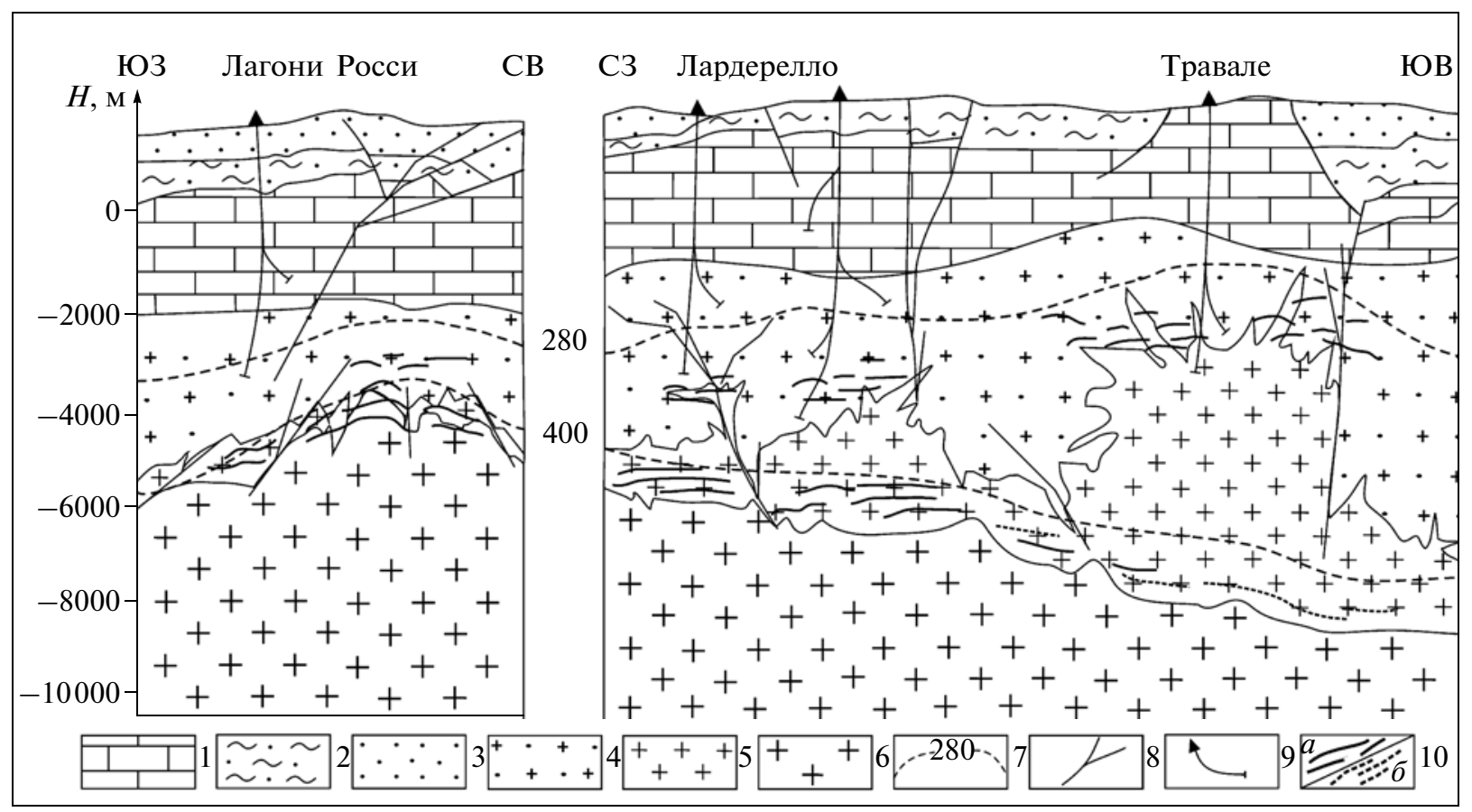

Рис. 5. Геологический разрез геотермального района Лардерелло-Травале [Casim et al., 2010].

1 - карбонатно-эвапоритовые отложения; 2 - филлиты; 3 - вулканогенно-осадочные породы; 4 - метаморфический фундамент; 5 - древние граниты; 6 - молодые граниты; 7 - изотермы $\left(280^{\circ} \mathrm{C}\right.$ - установленная на основании бурения скважин, $400^{\circ} \mathrm{C}$ - предполагаемая на основании комплекса геолого-геофизических данных); 8 - тектонические разрывные нарушения; 9 - скважины; 10 - тектонические маркеры (см. рис. 4): $a$ - установленные на основании бурения скважин и по сейсмологическим данным, $\sigma$ - предполагаемые.

щающие метаморфические породы и создания ореола трещинно-брекчиевых зон над и вокруг приподнятых тектоно-магматических блоков. В составе газов, играющих ключевую роль в подъеме флюидов и транспорте тепла, преобладает углекислый газ (система Монте-Амиата характеризуется, помимо $\mathrm{CO}_{2}$, большим количеством в составе газов $\mathrm{Hg}, \mathrm{H}_{2} \mathrm{~S}, \mathrm{HCl}$ и др. летучих). Лардерелло-Травале является одной из крупнейших в мире газо-гидротермальных систем, в недрах которого выделено гигантское пародоминирующее месторождение. Установленная электрическая мощность ГеоЭС, базирующаяся на эксплуатации этого месторождения, составляет $785 \mathrm{MB}_{\text {э }}$ при общей мощности ГеоЭС Италии 843 МВт $_{\text {э }}$ [Capetti et al., 2010]. О рудной минерализации в этой системе имеются скудные сведения, она практически не изучена. В то же время известно, что расположенная в этом же районе газо-гидротермальная система Монте-Амиата, возможно объединяющаяся на глубине более 5-7 км в единую систему с Лардерелло-Травале, характеризуется высоким содержанием ртути в составе газов. Ртуть образует сульфидные минеральные формы (киноварь и метациннабарит), ассоциирующие с кварц-карбонатными жилами и прожилками во вмещающих породах. Рудная минерализация, повидимому, характерна не только для палео-, но и для современного этапа развития газо-гидротермальной системы Монте-Амиата.

Какконде и Матсукава (Япония). Эти газо-гидротермальные системы и одноименные крупнейшие пародоминирующие геотермальные месторождения Японии расположены в северной части острова Хонсю (рис. 6). Район является промышленно развитым. В геологическом плане он представляет собой крупный длительноживущий вулканогенно-рудный центр. Современные и новейшие геологические структуры наследуют мезозойские. Как неоднократно отмечалось, меловой период является временем наиболее интенсивной магматической деятельности на территории Японских островов [Геологическое..., 1968]. Она привела к образованию многочисленных интрузий и мощных потоков лав и пирокластики от основного до кислого состава. Из интрузивных пород наиболее типичны диориты, гранодиориты, биотитовые граниты и кварцевые диориты, образующие магматические пояса овально-изометричной формы или вытянутые в север-северо-восточном направлении, площадью до 5000 км². Интрузии представляют собой корни вулканов, продуцирующих эффузивы среднего состава и более поздние кислые пирокластические отложения. Последние имеют средне-верхнемеловой возраст и образуют основную толщу пород мощностью до 1500 м в север- 


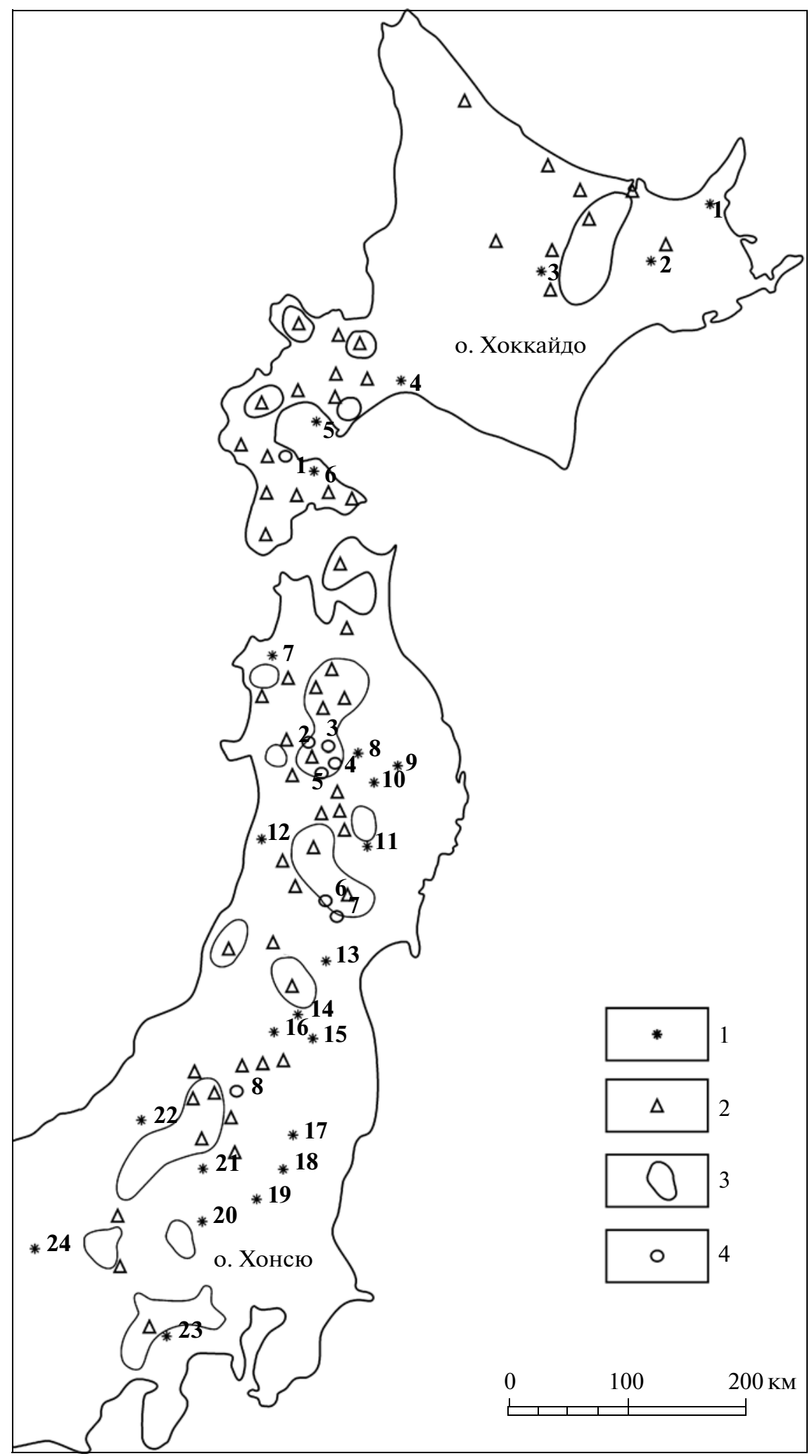

Рис. 6. Геотермальные и минеральные рудные ресурсы Северной Японии [Геологическое..., 1968].

1 - вулканы (1 - Сирэтоко, 2 - Мэакан, 3 - Токати, 4 - Таруман, 5 - Усу, 6 - Комагатакэ, 7 - Иваки, 8 - Акита-Якэяма, 9 - Иватэ, 10 - Акита-Комагатакэ, 11 - Курикома, 12 - Текай, 13 - Дзао, 14 - Адзума, 15 - Адатара, 16 - Бандай, 17 - Насу, 18 - Никко-Сиранэ, 19 - Акаги, 20 - Асама, 21 - Кусацу-Сиранэ, 22 - Ниигатэ-Акэяма, 23 - Фудзи, 24 Хакусан); 2 - рудные месторождения; 3 - поля развития гранитов; 4 - геотермальные системы (1 - Мори, 2 - Сумикава, 3 - Онума, 4 - Матсукава, 5 - Какконде, 6 - Енотан, 7 - Оникобэ, 8 - Яназу-Нишияма). 
ной части острова Хонсю. Считается, что с такими магматическими комплексами генетически связаны рудные месторождения: гипотермальные Mo-W, Sb-W и Au-Te; скарновые Fe, Cu и Pb-Zn руд; меденосные сульфидные; марганцевые; хромитовые; ртутные; никельсодержащие пирротиновые [Sekine, 1956].

Тектоно-магматическая деятельность в палеогене и неогене привела к образованию эшелонированных тектонических структур и двойных островных дуг, мощных толщ вулканогенно-осадочных пород, подвергшихся зеленокаменным изменениям, и дальнейшей гранитизации верхних горизонтов земной коры северного Хонсю. К этому периоду относится образование месторождений, играющих важную роль в экономике Японии: эпитермальных золото-серебряных, медно-свинцовоцинковых, типа Куроко, медно-хлоритовых, ртутных и др. [Geological..., 1960]. Произошло заложение геологических структур, контролирующих проявления нефти и газа, каменноугольные бассейны и крупные геотермальные аномалии. Четвертичная и современная вулканическая деятельность приурочена к внутренним тектоническим поясам Японской островной дуги и генетически связана с длительноживущими (от мела по голоцен) центрами кислого магматизма.

На вулканическом поле Какконде с целью поиска геотермального теплоносителя, обладающего высокими Р-Т-параметрами, глубокими скважинами вскрыт сложный магматический комплекс (рис. 7). Внедрение крупного батолита раннечетвертичных гранитов в дотретичные осадочные породы фундамента привело к подъему и дроблению этих пород и древних гранитов на тектонические блоки в кровле интрузии. Интрузия имеет сложное строение и представлена по меньшей мере двумя фазами: раннечетвертичными гранит-порфирами и позднечетвертичными (молодыми) гранитами. Предполагается, что возраст молодых гранитов не превышает 0.6 млн лет [Tamanyu, 1991]. Основная часть разреза сложена меловым лаво-пирокластическим комплексом пород (формация Кинимитогэ), верхняя часть разреза - вулканогенно-осадочными палеогеннеогеновыми отложениями (формация ТакиноеОнзен) и миоценовыми “зелеными туфами” (формация Яматсуда) [Shigeno, 2000; Uchida et al., 1996]. Толща пород прорвана голоценовыми кислыми магмами, образующими экструзии и действующие вулканы (см. рис. 6).

В качестве источника тепла для современной газо-гидротермальной системы рассматриваются нагретые сухие породы гранитного массива Какконде. В интервале глубин от 2 до 3 км ниже уровня моря перенос тепла осуществляется, в основном, кондуктивным способом, возможна циркуляция перегретого (более $400-500^{\circ} \mathrm{C}$ ) водного флюида по трещинам в неоднородной зоне контакта между гранитами раннего и позднего этапов. Коэффициент проницаемости гранитов Какконде составляет более 100 миллидарси, что превышает значения коэффициентов проницаемости для обычных гранитов [Tamanyu, Fujimoto, 2005]. Открытая пористость в гранитах образовалась после затвердевания магмы вследствие интенсивных гидротермально-метасоматических изменений пород [Fujimoto et al., 1998], преобразование пород происходило в гипо- и мезотермальных условиях. Современный глубинный геотермальный резервуар, по-видимому, имеет двухярусное строение. Нижняя зона представлена перегретым (более $400^{\circ} \mathrm{C}$ ) существенно жидким флюидом, циркулирующим в зоне контакта между гранитами раннего и позднего этапов и дотретичных осадочных пород. Зона сухого паро-газового флюида расположена в мегабрекчиевой оторочке гранитной интрузии в дезинтегрированных породах, ее кровля ограничена изотермой $350^{\circ} \mathrm{C}$.

Другая область перехода жидкость-пар локализуется в средней и верхней туфовых толщах формации Кинимитогэ и ограничена изотермами $260^{\circ} \mathrm{C}$ в основании резервуара и $220^{\circ} \mathrm{C}$ в его кровле (см. рис. 7). При этом подошва резервуара трассируется узкой зоной распространения вайракита, кровля - ломонтитом. Молодые и современные гидротермально-метасоматические породы накладываются на область распространения высокотемпературных палеогидротермальных изменений (биотит-кварцевая и гранат-биотит-кордиеритовая минеральные ассоциации). Последние образуют куполообразную зону, отражающую восходящий высокотемпературный тепловой поток над центральной частью древнего интрузивного комплекса гранитов Какконде.

Таким образом, модель газо-гидротермальной системы Какконде представляется следующим образом. Система включает два геотермальных резервуара. Глубинный локализован в контактовой зоне многофазных четвертичных остывающих гранитов, внедрившихся в осадочные породы фундамента и образовавших мегабрекчиевую проницаемую область над и вокруг интрузии. Температуры перегретого паро-газового флюида составляют от $500-450^{\circ} \mathrm{C}$ в подошве, до $350^{\circ} \mathrm{C}$ в кровле зоны перехода жидкость-пар. Малоглубинный (500-1700 м от дневной поверхности) геотермальный резервуар образован за счет восходящего существенно жидкого флюида при переходе его из относительно плотных, но трещиноватых пород основания формации Кинимитогэ в породы той же формации, отличающиеся повышенной открытой пористостью (трещиноватые гидротермально измененные туфы). Температура зоны кипения флюида составляет от 260 до $220^{\circ} \mathrm{C}$. Резервуар образует изометричную область размером в вертикальном сечении примерно $1.5 \times 1.5$ км. 


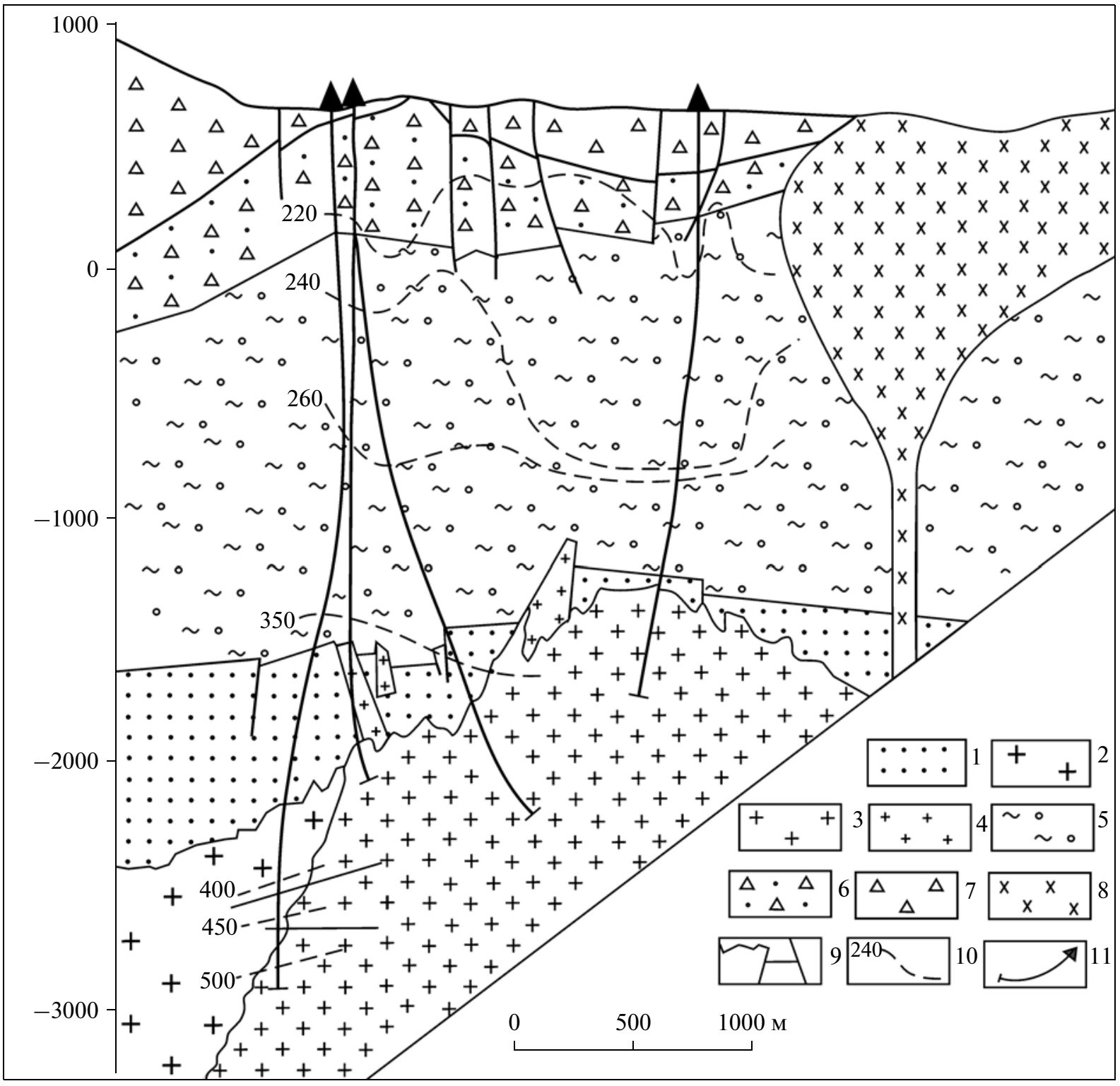

Рис. 7. Геологический разрез гидротермально-магматической системы Какконде и одноименного геотермального месторождения, Северное Хонсю [Uchida et al., 1996; Tamanya, Fujimoto, 2005].

1 - дотретичные осадочные породы; 2-3 - граниты интрузии Какконде: 2 - раннего этапа, 3 - позднего этапа; 4 древние граниты; 5 - комплекс вулканогенно-осадочных пород миоцен-плиоценового возраста; 6-7 - лавы и туфы среднего состава четвертичного возраста: 6 - формация Такиное-Онзен, 7 - формация Яматсуда; 8 - лаво-экструзивный комплекс дацитов голоценового возраста; 9 - тектонические нарушения и границы; 10 - изотермы, установленные по результатам бурения скважин; 11 - скважины.

Вероятно, аналогичные геотермальные резервуары могут быть вскрыты над апикальными частями других приподнятых блоков молодых гранитов. На основании глубокого бурения и анализа микросейсмических данных предполагается наличие связи между приповерхностным и глубинным геотермальными резервуарами за счет инфильтрации метеорных и смешанных вод в мегабрекчиевую экзоконтактовую зону интрузии и быстрого охлаждения гранитов [Tosha et al., 1998]. Видимо таким образом происходит смещение зоны хрупко-пластичного перехода пород на глубину и увеличение области конвективного переноса тепла с одновременным снижением Р-Т-параметров восходящего газо-гидротермального флюида. Это обстоятельство может иметь большое значение при разведке и эксплуатации геотермальных месторождений северного Хонсю в перспективе. Установленная мощность ГеоЭС Какконде составляет $80 \mathrm{MBT}_{\ni}$, Матсукава $23.5 \mathrm{MBT}_{\ni}$ [Sugino, Akeno, 2010], но прогнозные запасы тепла, заключенного в горных породах и газо-гидротер- 


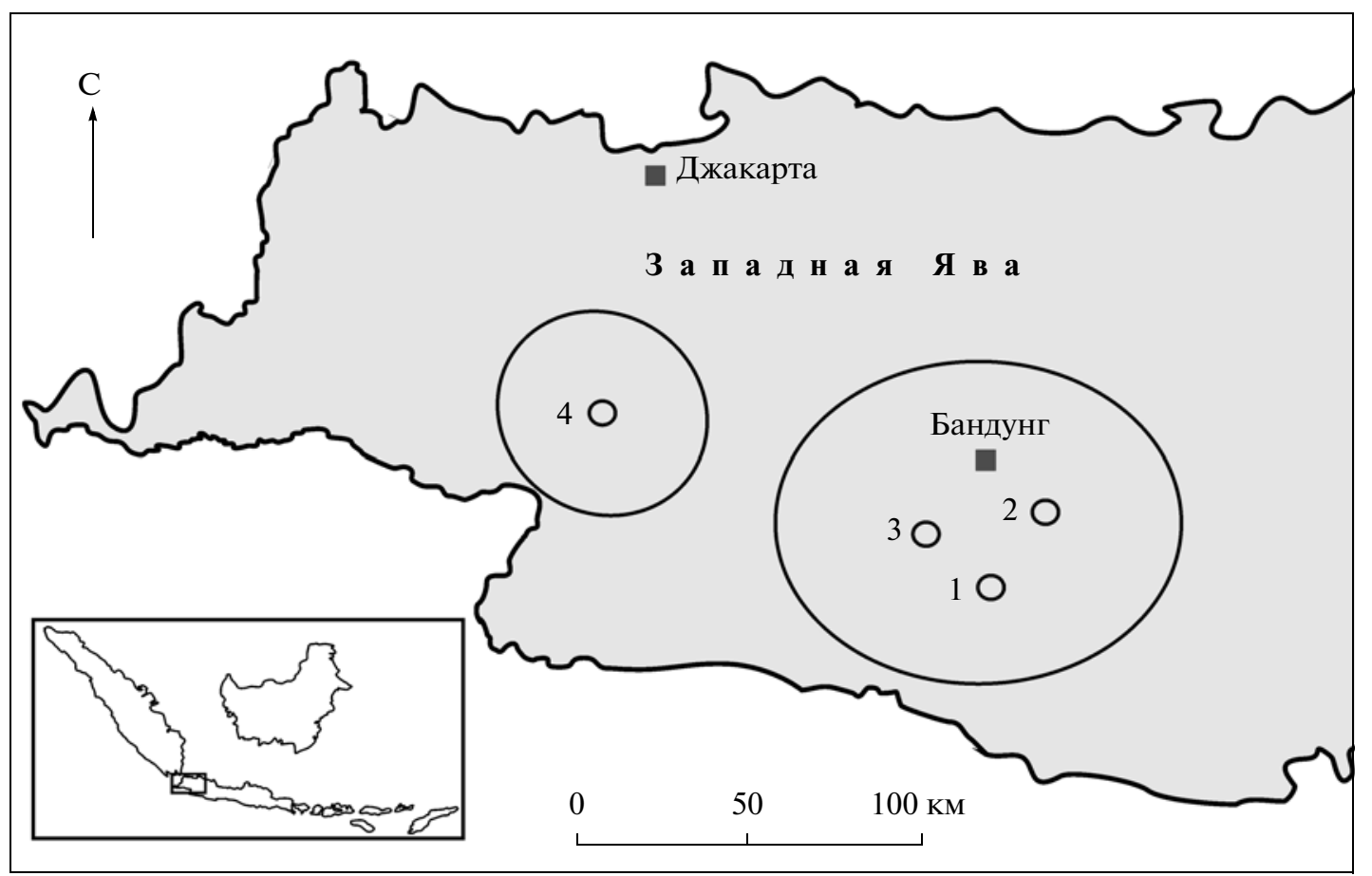

Рис. 8. Положение крупнейших газо-гидротермальных систем и геотермальных месторождений Индонезии (на врезке центральная часть Индонезийского архипелага и район исследований): 1 - Дараджат, 2 - Камоджанг, 3 - Вайонг Винду, 4 - Гунунг Салак. Остальные пояснения - см. текст.

мальных флюидах, по оценкам многих японских специалистов сопоставимы с геотермальными ресурсами Гейзерс и Лардерелло-Травале. Рудная минерализация, заключенная в породах гидротермально-магматической системы Какконде, разнообразна. Для палеоген-неогенового этапа развития системы характерно мезо- и эпитермальное золото-серебряное, полиметаллическое и ртутное оруденение, приуроченное к зонам контактов кислых интрузий и субвулканических тел с вмещающими породами. Современный этап минералорудообразования менее изучен и, повидимому, представлен прожилково-вкрапленной сульфидной минерализацией, ассоциирующей с кварц-халцедоновыми прожилками. Эта прожилково-вкрапленная рудная система локализуется в трещиноватых и пористых туфах формации Кинимитогэ над апикальными частями гранитных интрузий.

Дараджат, Камоджанг и Вайонг Винду (Индонезия). Индонезия занимает третье место в мире по установленным запасам (1196 МВт $)$ и производству геотермальной электрической энергии (8175 ГВТ/ч) после США и Филиппин [Bertani, 2010]. Прогнозные ресурсы оцениваются на порядок выше: $27 \Gamma_{\text {Гтт }}$ [Darma et al., 2010]. Основные геотермальные месторождения расположены в наиболее густонаселенном и промышленно развитом районе страны - Западной Яве: Камоджанг (энергетический потенциал $260 \mathrm{MBT}_{\ni}$ ), Дара- джат (260 $\mathrm{MB}_{\ni}$ ), Вайонг Винду (227 $\mathrm{MB}_{\ni}$ ), Гунунг Салак (377 $\mathrm{MBT}_{\ni}$ ) и несколько других месторождений с энергетическим потенциалом от 55 до $120 \mathrm{MBт}_{\text {э }}$ [Darma et al., 2010]. Гидротермально-магматические системы, вмещающие геотермальные месторождения, приурочены к внутренней зоне Индонезийской островной дуги и входят в состав крупных вулканических центров (рис. 8). Один из таких вулканических центров размером в плане $100 \times 120$ км включает газо-гидротермальные системы и пародоминирующие месторождения Камоджанг и Дараджат, а также систему Вайонг Винду смешанного типа (на современном этапе развития которой отчетливо проявлены и водо-, и пародоминирующий режимы).

Магматическая деятельность, определившая повышенный конвективный тепловой поток в районе Дараджат, началась в миоцен-плейстоценовое время с внедрения щелочных магм основного состава и образования тел микродиоритов и толеитовых лав в центре структуры [Rejeki et al., 2005]. На плейстоценовом этапе сформирован крупный андезибазальтовый стратовулкан. Дифференциация расплава в магматическом очаге привела к кальдерообразованию и отложению по периферии структуры мощных толщ пирокластики и лав от андезитов до риолитов. Обсидиановые потоки и риолитовые пепловые туфы отражают последний (средне-верхнечетвертичный) этап вулканической активности [Rejeki et al., 2005]. В 
историческое время известны извержения андезитовых вулканов Гунтур (1840г.), Папандуан (1772 г. и 2003 г.), и др. Близкая история развития предполагается для вулканических структур Камоджанг и Вайонг Винду, объединяемых таким образом вместе с с Дараджат в единый длительноживущий вулканический центр.

Вулканическое поле Дараджат ограничено полукольцевым разломом Кенданг и сложено множеством эруптивных центров и отдельных вулкано-плутонических купольно-кольцевых структур. Выделяется система “господствующих” СВ и поперечных С3 зон разрывных тектонических нарушений, разбивающих вулканическое поле на вытянутые или изометричные блоки размером в поперечнике до 1.0-1.5 км [Pramono, Colombo, 2005]. На основании бурения скважин показано, что разрез каждого блока неоднородный и отличается от разрезов смежных блоков литологическим строением (составом и мощностью горизонтов лав и туфов), структурой проницаемости, петрофизическими и др. свойствами пород [Hadi et al., 2005]. По-видимому, для вулканического поля Дараджат характерна типичная в целом для андезитовых вулканов и связанных с ними гидротермально-магматических систем неоднородная мозаично-блоковая структура: смежные блоки отличаются контрастными петрофизическими свойствами пород [Ладыгин, Рычагов, 1995]. Такая структура определяет динамику восходящего конвективного теплового потока и инфильтрацию метеорных вод на глубину [Рычагов, 1993].

На основании гравиметрических исследований в центральной части вулканического поля Дараджат выделена крупная положительная аномалия силы тяжести в виде куполообразной структуры, интерпретируемой как плотное интрузивное тело диоритов [Rejeki et al., 2010]. В кровле этой структуры на глубине от 1.5 до 2.5 км от дневной поверхности вскрыты микродиориты. По направлению от эндо-экзоконтактовой зоны интрузии к дневной поверхности последовательно выделяются следующие зоны гидротермально-метасоматических пород: наиболее высокотемпературная приконтактовая гранат-амфиболитовая, среднетемпературная хлорит-пирит-эпидот-кварциллитовая, иллит-вайракитовая и приповерхностная иллит-смектитовая [Rejeki et al., 2005]. Согласно гравиметрическим исследованиям четко выделяются области разуплотнения пород: обширная зона хлорит-пирит-эпидот-кварц-иллитовых метасоматитов мощностью до 1000 м над краевыми частями интрузии, плотность этих пород составляет 2.2 г см $^{3}$; более локализованная зона иллит-вайракитовых метасоматитов в надкупольной части интрузивного комплекса с плотностью пород

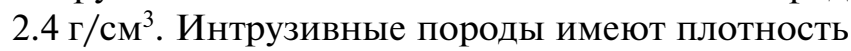

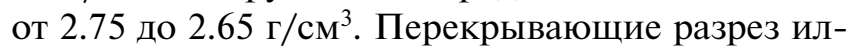

лит-смектитовые отложения мощностью от нескольких десятков метров в центре структуры до 500 м на ее флангах служат верхним водоупором и, вероятно, теплоизолирующим горизонтом. Плотность этих аргиллизированных тонкодисперсных, слабо проницаемых для трещинной и трещинно-поровой циркуляции парогидротерм, мине-

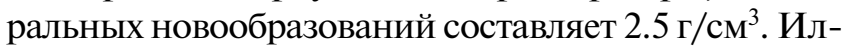
лит-вайракитовая зона, образующая "шапку" мощностью до 500 м над интрузивным куполом, диагностирует область кипения гидротерм. Породы продуктивных горизонтов, как правило, представляют собой крупнообломочные (от псефитовой до агломератовой размерности) ксеногенные туфы и брекчии туфов [Stimac et al., 2010]. Открытая эффективная пористость пород в таких зонах колеблется в пределах 10-30\%, достигая 50$70 \%$ на отдельных участках брекчий [Rejeki et al., 2005]. При этом не отмечается уменьшение объема трещинно-порового пространства на глубину, что, по-видимому, обусловлено формированием открытых пор и микротрещин на этапе гидротермально-метасоматического преобразования пород, а не вследствие первичных литологических процессов.

На основании электроразведочного зондирования область пород с низким сопротивлением отражает изометричную аномалию на глубине 1000-2500 м от дневной поверхности (рис. 9). Эти данные согласуются с экспериментами по закачке бурового раствора в скважины с одновременным проведением микросейсмических исследований (рис. 10). Реинжекция раствора и приостановка работы ГеоЭС вызвали увеличение гидростатического давления в резервуаре и образование очагов микроземлетрясений за счет гидроразрыва и формирования системы дополнительных открытых трещин во флюидонасыщенных породах [Pramono, Colombo, 2005]. Выделена относительно изометричная флюидопроводящая область на глубинах до 3.5 км от дневной поверхности и зона мощностью 1.0 км, простирающаяся на глубину до 4.5 км (см. рис. 10). Вероятно, эта зона соответствует области циркуляции высокотемпературного (надкритического ?) флюида, верхняя изометричная зона повышенной микросейсмичности области кипения гидротерм.

Таким образом, на основании комплекса геолого-геофизических данных предложена следующая модель газо-гидротермальной системы Дараджат (рис. 11). На глубинах от 1.0-1.5 до 4.0 км от дневной поверхности выделена область перехода жидкость-пар, имеющая зональное строение. Внутренняя зона представляет собственно область кипения гидротерм и переноса тепла флюидом в разуплотненных пропилитизированных вулканогенно-осадочных породах. Внешняя зона характеризуется низкой открытой пористостью и образована за счет выполнения трещинно-поро- 


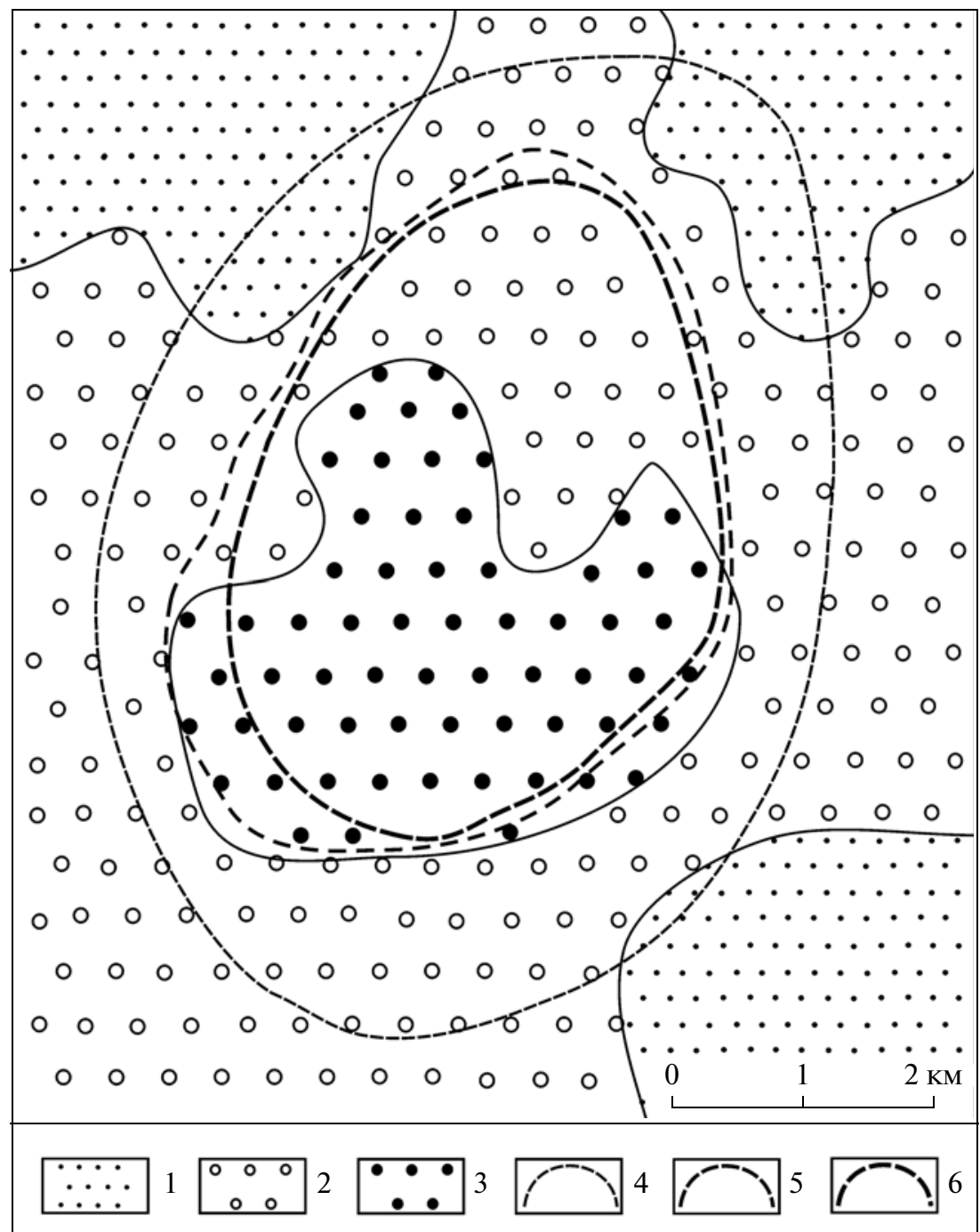

Рис. 9. Модель геотермального резервуара газо-гидротермальной системы Дараджат по данным электроразведочного зондирования [Rejeki et al., 2010].

1-3 - области распространения пород с высоким (1), средним (2) и низким (3) электрическим сопротивлением на глубине 2500 м от дневной поверхности; 4 - предполагаемая граница резервуара по общим геофизическим данным; 5 наиболее вероятная граница пародоминирующего геотермального резервуара по результатам электроразведочного зондирования; 6 - граница пародоминирующего геотермального резервуара, принятая для построения концептуальной модели.

вого пространства минералами кремнезема (тридимитом, кристобалитом, халцедоном и кварцем) в основании и вокруг области кипения. Эта зона может рассматриваться как своеобразный экран и теплоизолирующий горизонт. Тепловое питание газо-гидротермальной системы и ее связь с магматическим источником осуществляется за счет подъема глубинных флюидов по зонам отдельных разрывных тектонических нарушений. Вероятно, микроконвективные гидротермальные ячейки определяют перенос паро-газовой смеси внутри зоны кипения вдоль тектонических нарушений (см. рис. 11). Следовательно, Дараджат является примером самоизолирующейся конвективной гидротермальной системы с образованием круп- ного паро-газового резервуара (объемом $\geq 50 \mathrm{KM}^{3}$ ) и зоны циркуляции высокотемпературного (надкритического ?) жидкого флюида в подошве и краевых частях области кипения растворов. Самоизоляция, по-видимому, является одним из основных механизмов формирования крупных газо-гидротермальных систем с паровыми резервуарами [Жатнуев и др., 1996; Рычагов, 2003]. Интрузивный комплекс диоритов-микродиоритов, с которым пространственно и генетически связана газо-гидротермальная система, вероятно, представляет собой многофазную интрузию, уходящую корнями в область современного магматического очага. 


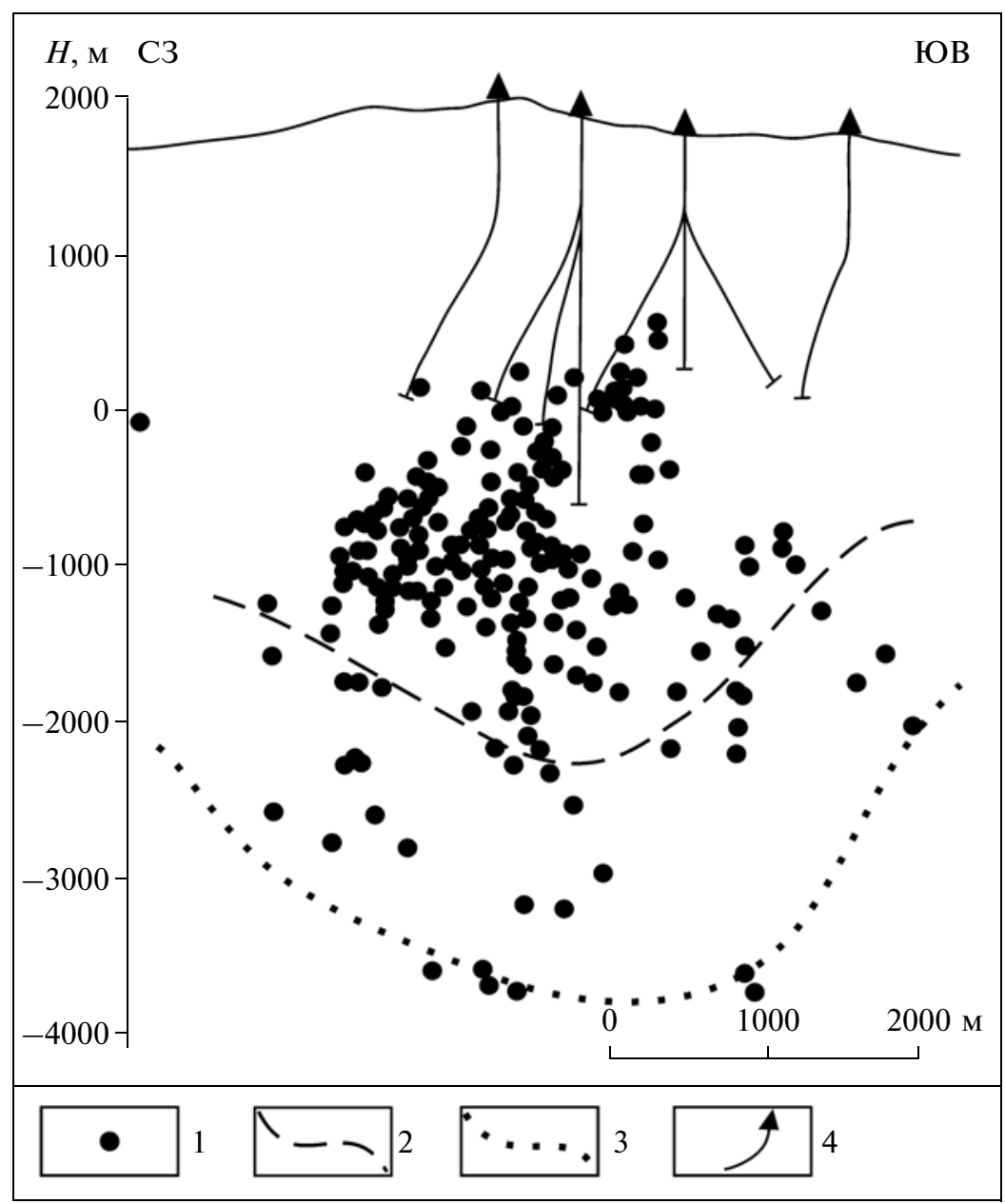

Рис. 10. Распространение очагов микроземлетрясений в разрезе газо-гидротермальной системы Дараджат [Rejeki et al., 2010].

1 - очаги микроземлетрясений; 2 - граница зоны повышенной микросейсмичности; 3 - граница зоны средней микросейсмичности; 4 - скважины.

Камоджанг является одной из наиболее изученных газо-гидротермальных систем и пародоминирующих геотермальных месторождений Азии [Allis, 2000; Dwikorianto et al., 2005; Sofyan et al., 2010; Sumintadireja et al., 2000; Utami, 2000]. Принципиально ее строение мало отличается от структуры системы Дараджат. Обратим внимание на системы другого типа. В последнее время в Индонезии было выделено несколько гидротермальных систем, в т.ч. Вайонг Винду, на первом этапе эволюции которой водный флюид характеризовался нейтральным $\mathrm{pH}$. Зоны гидротермальных изменений включают [Abrenica et al., 2010]: амфиболитовую, образующую изометричную область на глубине более 1400 м непосредственно над магматическим источником теплового питания (предположительно интрузией диоритов); иллитовую (900-1400 м), переходную (700-900 м) и смектитовую (0-700 м от дневной поверхности). Согласно изучению газово-жидких включе- ний во вторичных минералах температурные интервалы образования этих зон составляют соответственно: $>280^{\circ} \mathrm{C}, 240-280^{\circ} \mathrm{C}, 180-220^{\circ} \mathrm{C}$ и $100-180^{\circ} \mathrm{C}$ [Reyes, 1990]. Второй этап эволюции системы ознаменовался сменой нейтральной на окислительную обстановку, что связано с поступлением в верхние горизонты пород кислых вулканических газов ( $\mathrm{HCl}, \mathrm{HF}$ и др.). Так, содержание $\mathrm{Cl}$ в современных парогидротермах достигает 13000 ppm [Bogie et al., 2008]. На наш взгляд это указывает на раскисление расплавов в верхней части магматического очага и насыщение магматических газов галоидами, что определило формирование принципиально другой гидротермально-метасоматической зональности на данном этапе развития гидротермально-магматической системы. В надинтрузивной зоне восходящего теплового потока и над амфиболитовыми метасоматитами в интервале глубин 700-1500 м образована пирофиллит-диаспор-ангидритовая зона, перехо- 


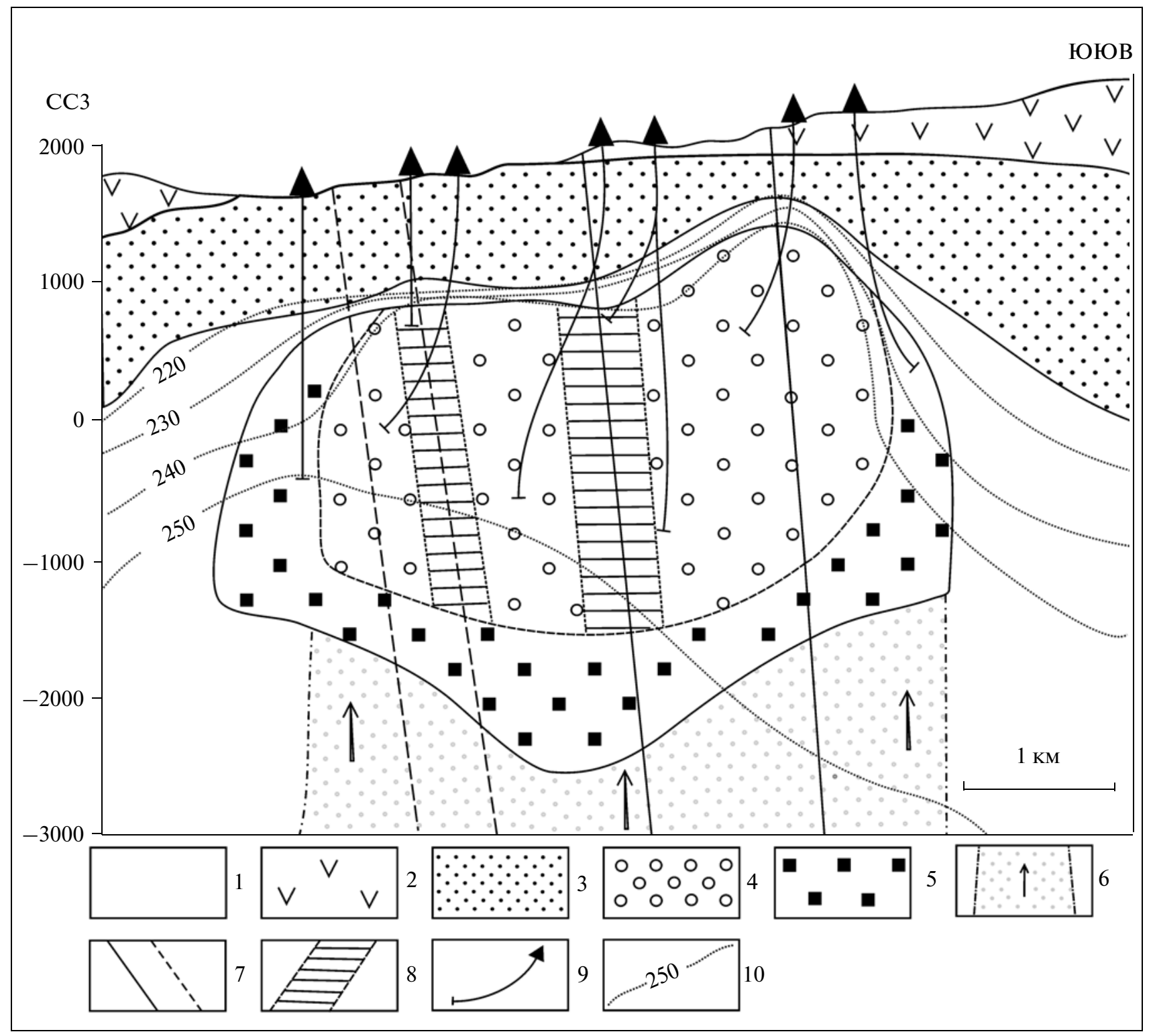

Рис. 11. Концептуальная модель газо-гидротермальной системы Дараджат [Rejeki et al., 2010] с изменениями и дополнениями.

1 - вмешающие вулканогенно-осадочные породы миоцен-плиоценового возраста; 2 - лавы и туфы голоценового возраста; 3 - четвертичные туфы и туффиты, аргиллизированные (верхний водоупор для гидротермальной системы); $4-$ область кипения гидротерм; 5 - подошва и краевые зоны области кипения, в которых трещинно-поровое пространство залечено вторичными минералами; 6 - зона восходящего потока газо-водного флюида; 7 - тектонические разрывные нарушения, установленные (сплошная линия) и предполагаемые; 8 - зоны повышенной проводимости (циркуляции парогидротерм) внутри области кипения растворов; 9 - скважины; 10 - изотермы.

дящая в каолинит-кальцит-кристобалит-кварцпиритовые (450-700 м), каолинит-алунитовые (150-450 м) и кристобалитовые (0-50 м) метасоматиты [Abrenica et al., 2010]. Последние две зоны связаны с дневной поверхностью за счет полной переработки исходных вулканогенно-осадочных пород по субвертикальным тектоническим нарушениям. Эта зональность отражает современный пародоминирующий режим газо-гидротермальной системы Вайонг Винду. Зоны вмещают от- дельные пародоминирующие резервуары изометричной формы в плане и уплощенные в вертикальных разрезах, локализованные в открытых разломах, погружающихся на глубину в область современного магматического очага. Вайонг Винду отличается от охарактеризованных выше систем большой ролью кислых газов и хлоридносульфатных растворов в формировании пародоминирующего режима, что может свидетельствовать в пользу неглубоко залегающего нагретого магма- 
тического тела диоритов - габбро-диоритов. Рудная минерализация, помимо пирита в одной из отмеченных выше метасоматических зон, не описана. Вероятнее всего это связано не с отсутствием минерализации, но обусловлено ориентировкой задач исследований на решение сугубо практических геотермальных проблем.

\section{КОШЕЛЕВСКАЯ ГАЗО-ГИДРОТЕРМАЛЬНАЯ СИСТЕМА (Южная Камчатка)}

Кошелевская система относится к ПаужетскоКамбально-Кошелевскому геотермальному (рудному) району [Рычагов и др., 2006]. Район входит в состав Южно-Камчатской геотермальной провинции [Сугробов, 1979] и расположен в пределах внутренней зоны Курило-Камчатской островной дуги на сочленении трех основных вулканических поясов Камчатки [Апрелков, 1971] (рис. 12). Район занимает центральное положение в субкольцевой тектоно-магматической структуре, представляющей собой пологий аккумулятивнотектонический свод размером $35 \times 50$ км, осложненный вулкано-тектонической депрессией четвертичного возраста размером в плане $20 \times 25 \mathrm{Kм}$ [Долгоживущий..., 1980]. Таким образом, Паужетско-Камбально-Кошелевский геотермальный (рудный) район отождествляется с длительноживущим вулканогенно-рудным центром [Прогнозная..., 1977]. В развитии района выделяется три структурных яруса: нижний представлен вулканогенно-осадочными породами олигоцен-среднемиоценового возраста, вмещающими многофазные интрузивные тела от габбро до плагиогранитов; средний образован вулканогенно-осадочными толщами среднего миоцена - плиоцена; верхний ярус отвечает за четвертичный этап развития островной дуги и сложен лавами, туфами и интрузивными породами плейстоцен-голоценового возраста среднего и кислого состава [Геолого-геофизический..., 1987].

Кошелевская газо-гидротермальная система непосредственно связана с одноименным вулканическим массивом олигоцен-голоценового возраста (рис. 13), состоящим из пяти сросшихся стратовулканов и отдельных моногенных построек [Вакин и др., 1976]. Массив образован на сочленении южнокамчатского и северокурильского сегментов островной дуги вследствие эволюции крупного периферического магматического очага, расположенного в зоне пересечения региональных разломов СВ и С3 простирания. На сквозькоровый характер разломов указывают данные магнито-теллурического зондирования, результаты изотопногеохимических исследований $\left({ }^{3} \mathrm{He} /{ }^{4} \mathrm{He},{ }^{87} \mathrm{Sr} /{ }^{86} \mathrm{Sr}\right)$, сведения о наличии восходящих потоков восстановленных флюидов, состоящих из углекислого газа, водорода, метана, тяжелых углеводородов [Лебедев, Декусар, 1980; Кононов, 1983; Поздеев, Нажалова, 2008; Поляк и др., 1979].
Разгрузка тепла, парогазовой смеси и гидротерм на дневной поверхности происходит в пределах Нижне- и Верхне-Кошелевского термальных полей (т/п), а также на отдельных участках структуры Кошелевского вулканического массива (см. рис. 13). Мощность т/п оценивается в 25 и 50 Гкал/с, соответственно [Вакин и др., 1976]. Суммарный вынос тепла парогазовыми струями сопоставим с тепловой мощностью Долины Гейзеров (Камчатка). Термальные поля отличаются структурным положением, Р-Т-параметрами теплоносителя, составом газов и гидротерм. НижнеКошелевское т/п расположено в глубоко врезанном овраге руч. Гремучий, трассирующего разлом, проницаемый для современных парогидротерм [Нуждаев, 2008; Феофилактов, Нуждаев, 2011]. В зоне гипергенеза образуются слабокислые до нейтральных и слабощелочных сульфатные и гидрокарбонатно-сульфатные аммониевые воды при температуре от 20 до $98^{\circ} \mathrm{C}$. Катионный состав смешанный, преобладают аммоний, $\mathrm{Ca}, \mathrm{Na}, \mathrm{K}$, $\mathrm{Fe}$, присутствуют $\mathrm{Al}, \mathrm{H}$, редкие щелочи и др. В составе растворенных и свободных газов преобладают $\mathrm{CO}_{2}, \mathrm{H}_{2} \mathrm{~S}, \mathrm{SO}_{2}, \mathrm{CH}_{4}$, азот и тяжелые углеводороды [Вакин и др., 1976; Рычагов и др., 2008]. Температура пара в отдельных фумаролах достигает $120^{\circ} \mathrm{C}$, преобладают значения температур грунтов и паро-водяной смеси в котлах и пульсирующих источниках 90-105 С [Рычагов и др., 2009].

Верхне-Кошелевское т/п локализовано в центральной части Кошелевского вулканического массива в эрозионном кратере вулкана Валентин и приурочено к контактовым зонам остывающего экструзивно-субвулканического комплекса андезидацитов. Характеризуется более высокими Р-Т-параметрами паро-газовых струй (до $150^{\circ} \mathrm{C}$ и до 7-10 атм. на устьях фумарол), значительной площадью прогрева грунтов (около $300 \times 500$ м), разгрузкой кислых и слабокислых сульфатных вод. На площади т/п много бессточных грязе-водных кипящих котлов, выделяющихся обилием взвеси самородной серы и пленок тонкодисперсного сульфида железа (пирита и марказита). При детальном гидрогеохимическом опробовании обнаружены разгрузки кислых термальных вод $(\mathrm{pH}=$ $=3.0-3.5, T=70^{\circ} \mathrm{C}$ ) с минерализацией до 2 г/л и содержанием растворенной и коллоидной кремнекислоты до 200 мг/л. Вследствие осаждения силикатного геля на обломках пород в настоящее время в ложе термального ручья активно образуются щеточки халцедона (руч. Халцедоновый в центре т/а). Также в отличие от Нижне-Кошелевского т/п на поверхности Верхне-Кошелевского поля образуются лимонит-гематитовые плащи за счет активного выщелачивания $\mathrm{Fe}$ и $\mathrm{Al}$ кислыми водами из вмещающих пород. Мощность плащей достигает 1.0-1.5 м, площадь 250-300 м². На фоне общего рассредоточенного выноса тепла фумаролами, грязе-водными котлами и парящими грун- 

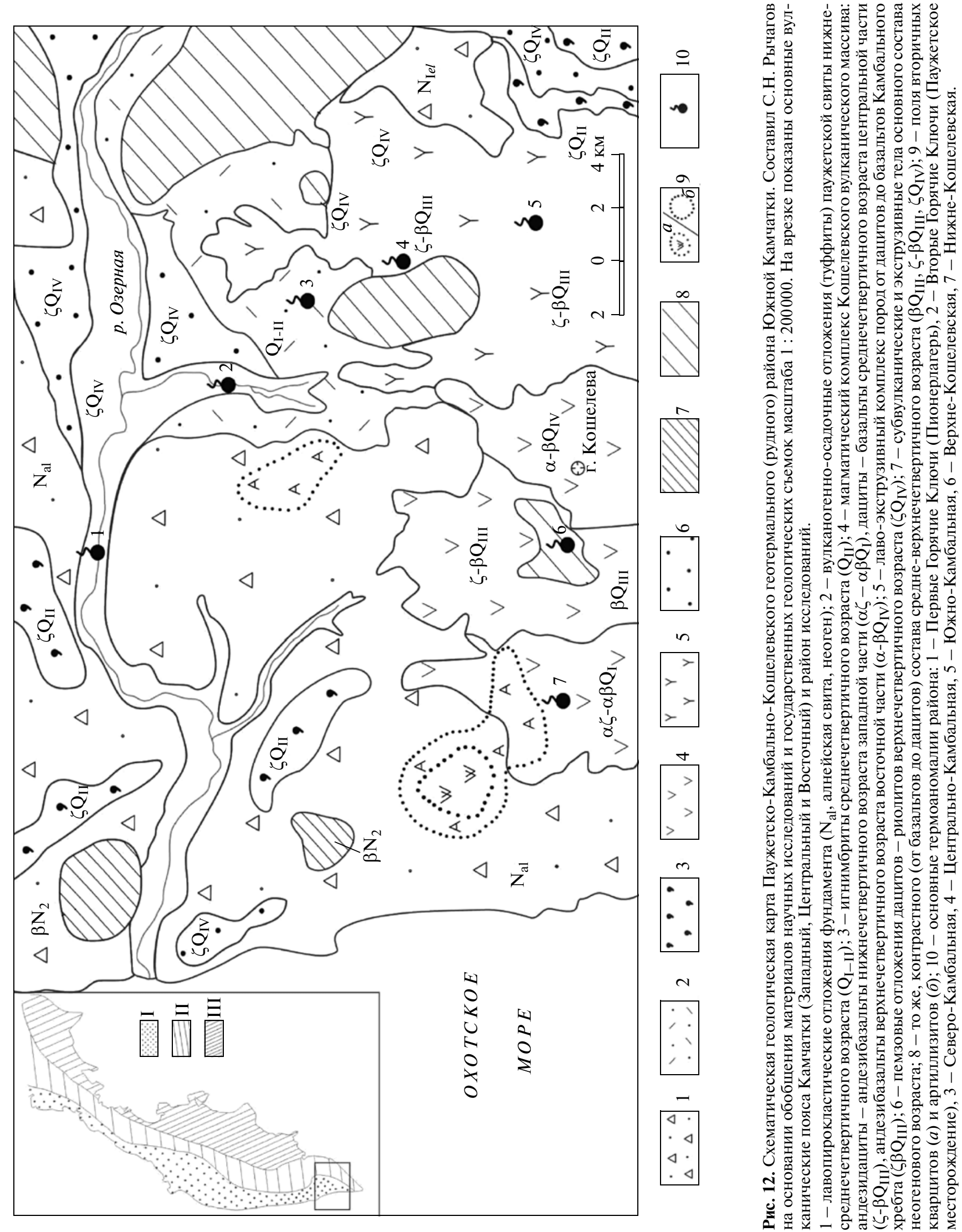


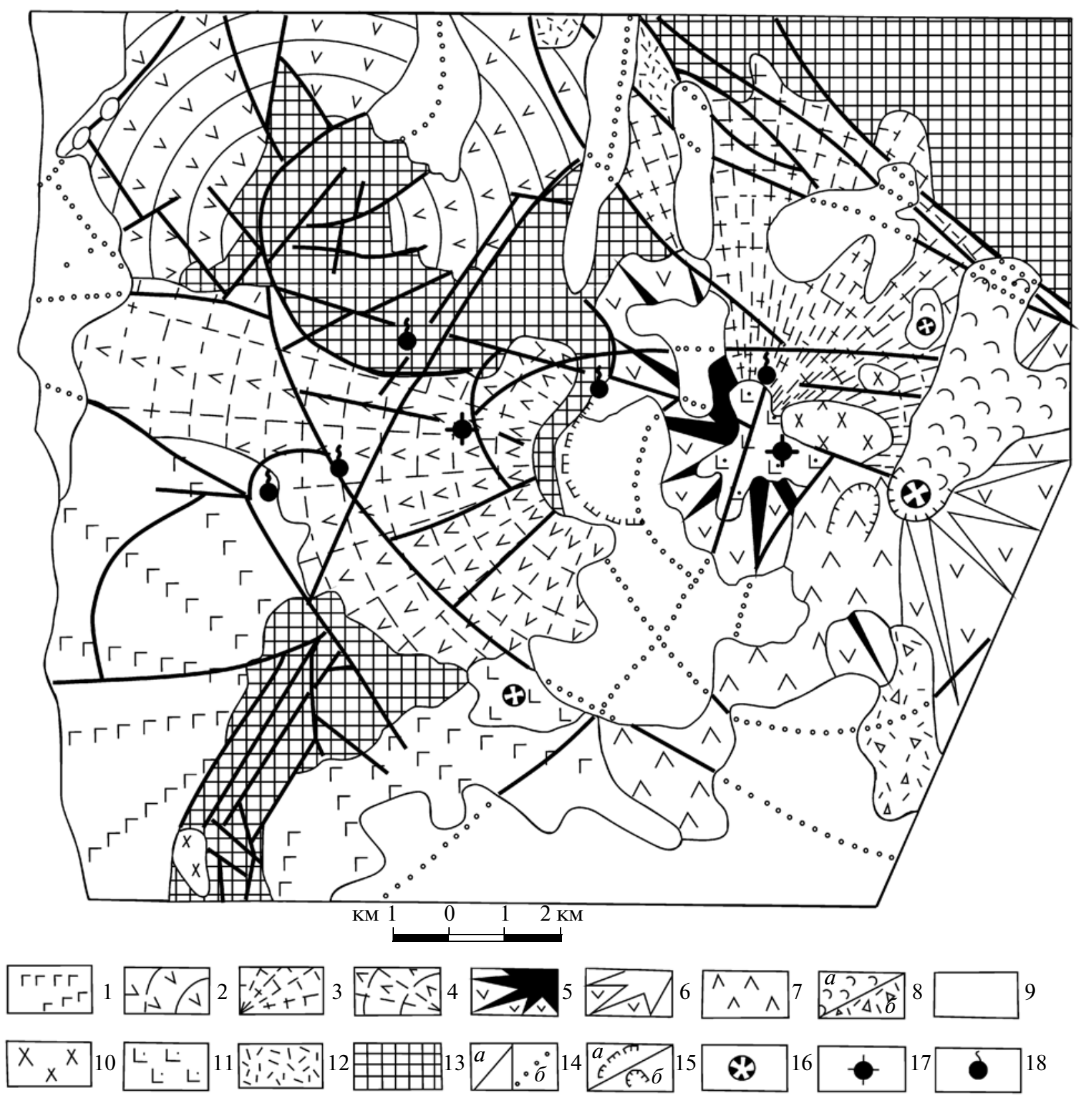

Рис. 13. Схематическая геологическая карта Кошелевского вулканического массива [Вакин и др., 1976] с изменениями.

$1-2$ - эффузивные и пирокластические отложения нижнечетвертичных вулканов: 1 - вулкан Дед и Баба $\left(\alpha \beta Q_{\mathrm{I}}\right), 2-$ вулкан Третья Речка $\left(\alpha \beta \mathrm{Q}_{\mathrm{II}}\right) ; 3-8$ - эффузивные и пирокластические отложения Кошелевского вулканического мас-

сива: 3 - вулкан Древний $\left(\alpha \mathrm{Q}_{\mathrm{II}}\right), 4$ - вулкан Западный $\left(\alpha \mathrm{Q}_{\mathrm{III}}^{1}\right), 5$ - вулкан Валентин $\left(\alpha \mathrm{Q}_{\mathrm{III}}^{2}\right), 6$ - вулкан Восточный $\left(\beta \mathrm{Q}_{\mathrm{III}-\mathrm{IV}}\right), 7$ - вулкан Центральный $\left(\alpha \beta \mathrm{Q}_{\mathrm{III}-\mathrm{IV}}\right) ; 8$ - образования Активного кратера $\left(\mathrm{Q}_{\mathrm{IV}}\right): a-$ лавовые потоки, $\sigma-$ отложения направленного взрыва; 9 - рыхлые отложения различного генезиса и возраста $\left(\mathrm{Q}_{\mathrm{II}}-\mathrm{Q}_{\mathrm{IV}}\right) ; 10-$ экструзии голоценового возраста; 11 - субвулканические интрузии долеритов ( $\left.\beta \mathrm{Q}_{\mathrm{III}-\mathrm{IV}}\right) ; 12$ - предположительно туфы кислого состава верхнепаужетской подсвиты; 13 - дочетвертичные эффузивы $\left(\alpha \mathrm{N}_{1}-\mathrm{N}_{2}\right) ; 14$ - разрывные нарушения: $a-$ установленные, $\sigma$ - предполагаемые; 15 - отрицательные структуры: а - кальдеры, б - эрозионные кратеры и воронки взрыва; 16 - эффузивные и экструзивные конусы; 17 - основные термоаномалии (I - Верхне-Кошелевская, II - Нижне-Кошелевская); 18 - локальные разгрузки термальных вод. 


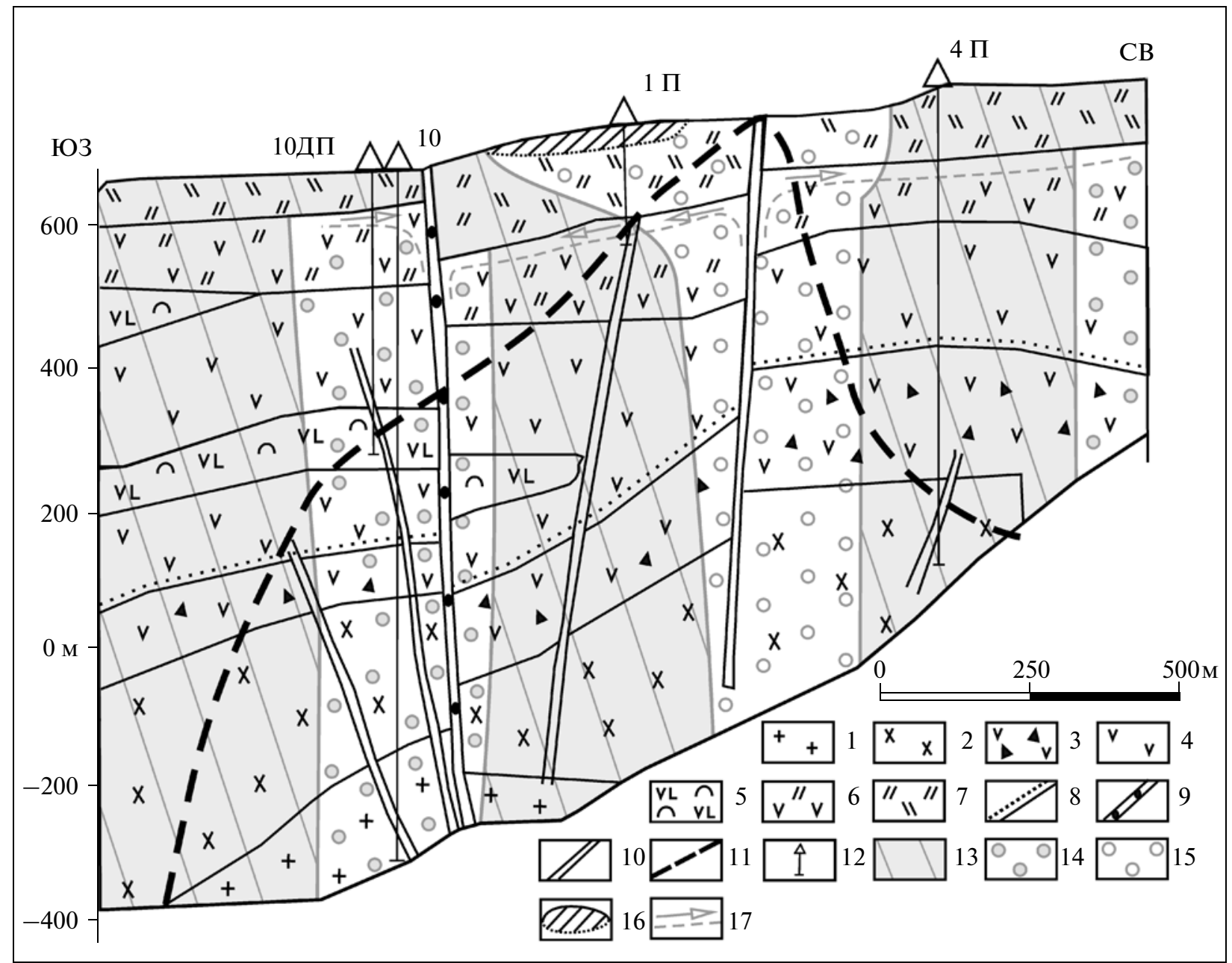

Рис. 14. Геологический разрез Нижне-Кошелевского пародоминирующего геотермального месторождения [Писарева, 1987] и строение современной и палеогидротермальной систем в разрезе месторождения по материалам исследований Южнокамчатско-Курильской экспедиции ИВиС ДВО РАН.

1 - диориты; 2 - диоритовые порфириты; 3 - мегабрекчии апикальной части интрузии; 4 - лавы андезитов; 5 - туфы и туффиты андезитов - андезибазальтов; 6 - лавы и туфы андезитов - андезидацитов; 7 - лавы и экструзии андезидацитов - дацитов; 8 - кровля интрузивного комплекса; 9 - разрывные тектонические нарушения, залеченные вторичными гидротермальными минералами; 10 - то же, проницаемые для современных гидротерм; 11 - граница зоны кипения гидротерм на основании гидродинамических испытаний в скважинах; 12 - скважины; 13 - блоки пород жесткие, высокоскоростные для микросейсмических волн и слабо проницаемые для гидротерм; 14 - блоки пород относительно разуплотненные, трещины и поры в которых залечены вторичными гидротермальными минералами; 15 - блоки пород разуплотненные - зона современного парообразования и восходящего газо-гидротермального потока; 16 - Нижне-Кошелевское Новое термальное поле (проекция на разрез); 17 - зоны перетока (циркуляции) конденсатных вод или (и) гидротерм, восходящих по субвертикальным трещинам.

тами выделяется руч. Тартарары: истоки ручья образуют пять крупных (от 3 до 7 м в диаметре) кипящих водных котлов, на протяжении 150 м по бортам и в русле ручья выходят перегретые (до $150^{\circ} \mathrm{C}$ ) парогазовые струи [Вакин и др., 1976; Феофилактов, Нуждаев, 2009]. Эта структура, обеспечивающая основной вынос тепла на ВерхнеКошелевском т/п и расположенная на ее восточном краю, по-видимому, приурочена к контактовой зоне экструзивно-субвулканического тела. В составе газов преобладают $\mathrm{CO}_{2}, \mathrm{H}_{2} \mathrm{~S}, \mathrm{SO}_{2}$; сумма кислых газов может достигать $97 \%$ от объема сухого газа; со- держание водорода, метана и др. углеводородов в сумме не превышает 1.5 об. \% [Вакин и др., 1976]. Изложенные данные позволяют предполагать, что источником газов и переносимых ими рудных химических соединений для Верхне-Кошелевского термального поля служит неглубоко залегающее интрузивное тело диоритов - габбро-диоритов.

Нижне-Кошелевское геотермальное месторождение разведано в 1975-1984 гг. В результате бурения глубоких скважин в интервале 300-1200 м от дневной поверхности вскрыто многофазное интрузивное тело (рис. 14). Центральная его часть 
сложена диоритами, выше постепенно (?) переходящими в диоритовые порфириты. Апикальная часть представляет собой зону мегабрекчий, сложенную блоками интрузивных и вмещающих пород, сцементированных интрузивными (автомагматическими) брекчиями. Вмещающими породами являются туфы и туффиты среднего состава, вероятно, плиоценового возраста. Лаво-экструзивный комплекс андезидацитов служит верхним водоупором в гидротермальной системе. На основании гидродинамических испытаний разведочных скважин выделена зона перегретого (“сухого”) пара, распространяющаяся на глубину более 1500 м и выклинивающаяся на дневной поверхности в районе термального поля. Прогнозные ресурсы месторождения оценены в 210 кг/с сухого пара, что эквивалентно 90 МВт электрической мощности [Писарева, 1987]. Предполагается, что гидрогеологическая структура района НижнеКошелевского месторождения гидродинамически связана с Верхне-Кошелевским т/п [Поздеев, Нажалова, 2008] и таким образом в недрах Кошелевского вулканического массива может существовать единая крупная газо-гидротермальная система. Прогнозные геотермальные ресурсы этой системы оцениваются $\geq 300 \mathrm{MBT}_{\text {э }}$ [Стратегия..., 2001], что ставит ее в один ряд с крупнейшими газо-гидротермальными системами мира. В недрах Нижне-Кошелевского геотермального месторождения на начальном этапе развития гидрогеологической структуры, по-видимому, существовал смешанный водо-пародоминирующий режим. В геологическом разрезе снизу вверх устанавливается типичная для вододоминирующих систем зональность: гипабиссальная фация кварц-эпидотальбитовых пропилитов сменяется на субвулканическую фацию кварц-хлорит-цеолит-пиритовых пропилитов и субповерхностные карбонатизированные и аргиллизированные породы [Поздеев, Нажалова, 2008]. Есть основания полагать, что в экзоконтактовых зонах интрузий развиты кварцадуляровые метасоматиты и монокварциты, обычно образующиеся вследствие кипения кислых перегретых растворов. Вероятно, мегабрекчиевая оторочка интрузивного тела служит зоной перетока высокотемпературных (надкритических ?) гидротермальных растворов как на палео-, так и современном этапе эволюции системы.

На основании детальных геолого-геофизических исследований Южнокамчатско-Курильской экспедиции ИВиС ДВО РАН с использованием методов высокоточной гравиметрии, микросейсмического зондирования и магнитометрии уточнено глубинное строение зоны перегретого пара и центральной части Нижне-Кошелевского месторождения [Абкадыров и др., 2010; Феофилактов, Нуждаев, 2011]. Зона представлена субвертикальными блоками пород, обладающих контрастными петрофизическими свойствами: разуплотнен- ными (проницаемыми для парогидротерм) и плотными (жесткими, слабо проницаемыми для газо-водных флюидов) (см. рис. 14). Центральная проводящая зона распространяется на глубину до 2.0 км и “растворяется” в недрах интрузивного тела; вблизи дневной поверхности она имеет форму чаши, где микропоры в аргиллизированных до гидротермальных глин породах заполнены парогазовой смесью. На флангах разреза выделяются блоки, характеризующиеся низкими скоростями сейсмических волн. Эти блоки сложены метасоматитами (разуплотненными породами), образованными на палеогидротермальном этапе развития системы. Рудообразование в недрах системы связано с вторичными кварцитами, монокварцитами и кварцевыми жилами, вскрытыми эрозией в основании Кошелевского вулканического массива (палеогидротермальная система Третья Речка, локализованная в неогеновых вулканитах). Метасоматиты и кварцевые жилы включают рассеянную и прожилковую сульфидную минерализацию. Исходя из анализа состава геохимических ореолов, выявленных в процессе государственной геологической съемки масштаба 1 : 200000, оруденение имеет металлогеническую специализацию ( $\mathrm{Au}, \mathrm{Ag}, \mathrm{Cu}, \mathrm{Hg}$, др.), характерную для мезо- и эпитермального рудообразования. Минералорудообразование на современном этапе развития системы может быть связано с выделенными в ее недрах гидротермально-метасоматическими зонами [Поздеев, Нажалова, 2008] и предполагаемыми нами кварц-адуляровыми и монокварцевыми телами в экзоконтактовых зонах интрузий. Такая геологическая и минералого-геохимическая обстановка, в целом, типична для длительноживущих гидротермально-магматических систем, локализованных в вулкано-плутонических комплексах Курило-Камчатской островной дуги [Рычагов, 1993; Рычагов и др., 2002; Структура..., 1993]. Установлено также, что современные восходящие гидротермы являются металлоносными [Рычагов, Щегольков, 2011; Рычагов и др., 2012]. Получены дополнительные данные о металлогенической специализации растворов и минеральных новообразований, подтверждающие сквозькоровый характер газо-гидротермальной системы в районе Нижне-Кошелевского геотермального месторождения [Рычагов и др., 2010].

Другие газо-гидротермальные системы Курило-Камчатской островной дуги, которые предположительно можно отнести к гигантским, слабо или совсем не разбурены. Это системы кальдеры Узон и Долины Гейзеров (Восточная Камчатка) и Северо-Парамуширская (Северные Курильские острова). Три глубокие геотермальные скважины (от 1.1 до 2.5 км) вскрыли в пределах Северо-Парамуширской системы водоносный горизонт термальных вод $\left(130-160^{\circ} \mathrm{C}\right)$ на глубине $700-1300$ м в одном тектоническом блоке и сухие горячие поро- 
ды, нагретые до $210-220^{\circ} \mathrm{C}$ на глубине 2-2.5 км, в другом блоке [Рычагов и др., 2002]. Существует область активной циркуляции газо-гидротермального флюида в районе кратерной зоны вулкана Эбеко [Rychagov et al., 2010]. Но полученной информации недостаточно для отнесения этой системы к водо-, пародоминирующему или смешанному типу. Поэтому в данной работе мы ограничились описанием Кошелевской газо-гидротермальной системы.

\section{ЗАКЛЮЧЕНИЕ}

Гигантские газо-гидротермальные системы образуются в различных геодинамически подвижных структурах Земли: зонах глубинных разломов на границе океанических и континентальных тектонических плит, вулканических островных дугах, областях тектоно-магматической активизации. Все эти структуры характеризуются повышенными кондуктивным и конвективным тепловыми потоками. Высокий уровень кондуктивного теплового потока определяется подъемом региональных блоков горных пород за счет мантийного апвеллинга или согласно другим механизмам подъема магматических расплавов и интрателлурических (по Д.С. Коржинскому) флюидов в нижней части земной коры. Повышенный конвективный тепловой поток обусловлен внедрением в верхние горизонты земной коры интрузий от среднего до кислого состава. Дифференциация периферических магматических очагов приводит к формированию вулканических (вулканогеннорудных) центров, на заключительном (кальдерообразующем) этапе развития которых отлагаются мощные толщи кислых туфов и игнимбритов. Таким образом, формируются крупные осесимметричные вулкано-тектонические структуры и гидротермально-магматические системы в их недрах. Водное питание систем обеспечивают образующиеся в кальдерах крупные артезианские бассейны. Основу водного питания газо-гидротермальных систем (по оценкам большинства исследователей до 90-95\%) составляют воды метеорного и морского происхождения. Тепловое питание определяют дифференцированные магматические очаги и многофазные интрузивные тела от габбро-диоритов и диоритов до гранит-порфиров.

В составе восходящего конвективного теплового потока большую роль играют газы магматического и гидротермального происхождения: $\mathrm{CO}_{2}>$ $>\mathrm{CH}_{4}>\mathrm{HCl}>\mathrm{HF}>\mathrm{H}_{2}$, др. летучие. Повышенное содержание углекислого газа, тяжелых углеводородов, водорода, восстановленного азота, ртути, соединений хлора и фтора указывает на наличие глубинного источника теплового и флюидного питания гидротермально-магматических систем. Для таких систем установлен сквозькоровый характер геологической структуры и предполагает- ся мантийное питание. Некоторые системы или их отдельные блоки считаются перспективными на горючий газ. К подобным сквозькоровым геологическим структурам относится, в частности, Нижне-Кошелевская геотермальная аномалия, образованная в зоне глубинного разлома на участке сочленения южнокамчатского и северокурильского сегментов островной дуги. Кислые газы характеризуют неглубоко залегающие гидротермальные системы, локализованные над малыми интрузиями и субвулканическими телами габбро-диоритов, кварцевых диоритов и гранитпорфиров. Такая обстановка типична для гидротермальных систем, функционирующих в кратерных зонах крупных вулканических массивов: Верхне-Кошелевской и, возможно, Северо-Парамуширской.

Флюиды, циркулирующие в структуре гигантских газо-гидротермальных систем, являются металлоносными. Наличие в составе флюидов лигандов (галогенид-, тиосульфат-, цианид-, сульфид- и полисульфид-ионов) приводит к образованию соответствующих комплексных соединений и химическому транспорту металлов [Рычагов и др., 2012]. В зоне восходящего конвективного теплового потока, как правило, происходит растворение минералов и комплексных соединений, образованных металлами переменной валентности (Fe, Ti, $\mathrm{Au}, \mathrm{Ag}, \mathrm{Hg}$ и др.), и насыщение растворов. В зоне гипергенеза гидротермальных систем (приповерхностной разгрузки гидротерм) при резком изменении Р-Т-параметров и геохимических характеристик растворов происходит разрушение и переход комплексных соединений металлов в сульфиды, оксиды, гидроксиды, силикаты и карбонаты. Индикатором процессов транспорта и отложения металлов служат аргиллизированные породы и гидротермальные глины, образующие высокодинамичную коллоидно-дисперсную минералого-геохимическую систему [Рычагов и др., 2010].

С газо-гидротермальными системами связаны крупнейшие в мире пародоминирующие геотермальные месторождения. Энергетический потенциал таких месторождений составляет $\geq 100 \mathrm{MBT}_{\text {э }}$ и может достигать $1500 \mathrm{MBT}_{\ni}$. Они обеспечивают выработку основного объема геотермальной электрической энергии в ряде стран (США, Италии, Мексике, Японии, Индонезии, Филиппин) и являются высоко перспективными для решения энергетических проблем во многих регионах мира, в т.ч. Дальнего Востока России. Геотермальные резервуары пародоминирующего типа (зоны перехода жидкость-пар, по [Жатнуев и др., 1996]) имеют, как правило, трехярусное строение. Область перегретого (“сухого”) пара локализуется над источником магматического тепла (остывающими многофазными интрузиями) в вулканических породах, характеризующихся повышенной 
трещинно-поровой проницаемостью (туфах и брекчиях). Над этой областью образуется зона конденсации паро-газового флюида, что приводит к массовому залечиванию открытых пор и трещин вторичными минералами (чаще всего минералами кремнезема и алюмосиликатами) и созданию дополнительного водоупора и теплоизолирующего горизонта мощностью до 1000 м [Рычагов и др., 2002]. В основании области кипения залегает высокотемпературный вододоминирующий резервуар, приуроченный к сложной по составу мегабрекчиевой мантии многофазных интрузий. В зоне перехода жидкость-пар происходит активная миграция рудных химических соединений, создание минеральной рудной зональности и транспорт комплексных соединений металлов из глубинных горизонтов в зону гипергенеза геотермальных аномалий.

На основании изложенного необходимо отметить, что газо-гидротермальные системы являются определенным типом длительноживущих гидротермально-магматических систем, для которых особое значение имеет перенос тепла и различных химических соединений глубинным газонасыщенным флюидом. Гигантские газо-гидротермальные системы и образующиеся в их недрах на современном этапе пародоминирующие геотермальные месторождения представляют огромный интерес для фундаментальной науки с целью изучения механизмов транспорта тепловой энергии и рудных соединений на различных горизонтах земной коры и для прогноза энергетических и минеральных ресурсов областей современного и древнего вулканизма.

Автор благодарен В.И. Белоусову, С.Ф. Главатских, Н.С. Жатнуеву, А.Д. Коробову, Г.П. Королевой, В.М. Ладыгину, Е.И. Сандимировой и другим коллегам по научной работе, внесшим неоценимый вклад в развитие основных положений данного исследования; молодым коллегам по экспедициям А.А. Нуждаеву, Р.Г. Давлетбаеву, И.Ф. Абкадырову, Ю.Ю. Букатову, И.А. Нуждаеву, С.О. Феофилактову, О.В. Ковиной (Кравченко), М.С. Чернову и др. за практическое участие в совместных полевых работах на вулканах и геотермальных месторождениях.

Работа выполнена при финансовой поддержке Российского фонда фундаментальных исследований (проект 13-05-00262-а) и Президиума ДВО РАН (проект 12-I-П27-05).

\section{СПИСОК ЛИТЕРАТУРЫ}

Абкадыров И.Ф., Горбатиков А.В., Степанова М.Ю., Букатов Ю.Ю. Опыт применения метода микросейсмического зондирования на геотермальных полях на примере Нижне-Кошелевской термоаномалии (Южная Камчатка) // Материалы IX региональной молодежной научной конференции "Природная среда Камчатки". Петропав-
ловск-Камчатский, 12-13 апреля 2010 г. ПетропавловскКамчатский: ИВиС ДВО РАН, 2010. С. 49-60.

Апрелков C.E. Тектоника и история вулканизма Южной Камчатки // Тектоника. 1971. № 2. С. 105-111.

Белоусов В.И., Рычагов С.Н., Сугробов В.М. Северо-Парамуширская гидротермально-магматическая система: геологическое строение, концептуальная модель, геотермальные ресурсы // Вулканология и сейсмология. 2002. № 1. С. 34-50.

Вакин Е.А., Декусар З.Б., Сережников А.И., Спиченкова M.B. Гидротермы Кошелевского вулканического массива // Гидротермальные системы и термальные поля Камчатки. Владивосток: ДВНЦ АН СССР, 1976. С. $58-84$.

Геологическое развитие Японских островов. М.: Мир, 1968. $720 \mathrm{c}$.

Геолого-геофизический атлас Курило-Камчатской островной системы / Под ред. Сергеева К.Ф., Красного М.Л. Л.: ВСЕГЕИ, 1987. 36 Л.

Долгоживущий центр эндогенной активности Южной Камчатки. М.: Наука, 1980. 172 с.

Жатнуев Н.С., Миронов А.Г., Рычагов С.Н., Гунин В.И. Гидротермальные системы с паровыми резервуарами (концептуальные, экспериментальные и численные модели). Новосибирск: Наука, 1996. 184 с.

Кононов В.И. Геохимия термальных вод областей современного вулканизма (рифтовых зон и островных дуг) // Труды ГИН РАН. Вып. 379. М.: Наука, 1983. 216 с.

Коржинский Д.С. Теория метасоматической зональности. М.: Наука, 1982. 104 с.

Ладыгин В.М., Рычагов С.Н. Гидротермальная система вулкана Баранского, о-в Итуруп: блоковая структура и интенсивность гидротермально-метасоматического перерождения пород по петрофизическим данным // Вулканология и сейсмология. 1995. № 5. С. 28-44.

Лебедев М.М., Декусар З.Б. Проявление углеводородов в термальных водах Южной Камчатки // Вулканология и сейсмология. 1980. № 5. С. 93-97.

Нуждаев А.А. Новые результаты изучения Верхне- и Нижне-Кошелевской термоаномалий // Материалы VI региональной молодежной научной конференции, Петропавловск-Камчатский, 26-27 ноября 2008 г. Петропавловск-Камчатский: КамГУ им. В. Беринга, 2008. C. 43-49.

Писарева М.В. Зона природного пара Нижнекошелевского геотермального месторождения // Вулканология и сейсмология. 1987. № 2. С. 52-63.

Поздеев А.И., Нажалова И.Н. Геология, гидродинамика и нефтегазоносность Кошелевского месторождения парогидротерм // Вулканология и сейсмология. 2008. № 3. С. 32-45.

Поляк Б.Г., Толстихин И.Н., Якуцени В.П. Изотопный состав гелия и тепловой поток - геохимический и геофизический аспекты тектогенеза // Геотектоника. 1979. № 5. С. 3-23.

Прогнозная оценка рудоносности вулканогенных формаций. М.: Недра, 1977. 296 с.

Рычагов С.Н. Гидротермальная система вулкана Баранского, о-в Итуруп: модель геологической структуры // Вулканология и сейсмология. 1993. № 2. С. 59-74. 
Рычагов С.Н. Эволюция гидротермально-магматических систем островных дуг: Автореф. дис. ... докт. геоЛ.-мИН. наук. М.: ИГЕМ РАН, 2003. 50 с.

Рычагов С.Н., Белоусов В.И., Белоусова С.П. Иерархическая система геотермальных рудообразующих структур. Новый взгляд на генерацию геотермальной энергии в областях современного вулканизма // Вулканизм и геодинамика. Материалы III Всероссийского симпозиума по вулканологии и палеовулканологии, УланУдэ, 5-8 сентября 2006 г. Иркутск: ИГХ СО РАН, 2006. T. 3. C. 761-766.

Рычагов С.Н., Белоусов В.И., Главатских С.Ф. и др. Северо-Парамуширская гидротермально-магматическая система: характеристика глубокого геологического разреза и модель современного минералорудообразования в ее недрах // Вулканология и сейсмология. 2002. № 4. С. 3-21.

Рычагов С.Н., Главатских С.Ф., Сандимирова Е.И. Рудные и силикатные магнитные шарики как индикаторы структуры, флюидного режима и минералорудообразования в современной гидротермальной системе Баранского (о-в Итуруп) // Геология рудных месторождений. 1996. Т. 38. № 1. С. 31-40.

Рычагов С.Н., Давлетбаев Р.Г., Ковина О.В. Гидротермальные глины и пирит геотермальных полей: значение в геохимии современных эндогенных процессов (Южная Камчатка) // Вулканология и сейсмология. 2009. № 2. C. 39-56.

Рычагов С.Н., Давлетбаев Р.Г., Ковина О.В. и др. Миграция катионов в гидротермальных глинах: к вопросу о критериях металлоносности газо-гидротермальных флюидов геотермальных месторождений Южной Камчатки // Вулканология и сейсмология. 2012. № 4. C. 23-36.

Рычагов С.Н., Давлетбаев Р.Г., Ковина О.В., Королева Г.П. Характеристика приповерхностного горизонта гидротермальных глин Нижне-Кошелевского и Паужетского геотермальных месторождений // Вестник КРАУНЦ. Науки о Земле. 2008. № 2. Вып. 12. С. 116-134.

Рычагов С.Н., Соколов В.Н., Чернов М.С. Гидротермальные глины как высокодинамичная коллоидно-дисперсная минералого-геохимическая система // ДАН. 2010. T. 435. C. 806-809.

Рычагов С.Н., Щегольков Ю.В. Минеральные новообразования на поверхности зерен пирита Нижне-Кошелевской геотермальной аномалии (Южная Камчатка) // Руды и металлы. 2011. № 2. С. 52-57.

Стратегия развития топливно-энергетического потенциала Дальневосточного экономического района до 2020 г. Владивосток: Дальнаука, 2001. 112 с.

Структура гидротермальной системы. М.: Наука, 1993. 298 c.

Сугробов В.М. Геотермальные ресурсы Камчатки, классификация и прогнозная оценка // Изучение и использование геотермальных ресурсов в вулканических областях. М.: Наука, 1979. С. 26-35.

Феофилактов С.О., Нуждаев И.А. Новые данные о распределении температур грунтов в районе Верхне-Кошелевских паровых струй // Материалы VII региональной молодежной научной конференции, Петропавловск-Камчатский, 25 ноября 2009 г. ПетропавловскКамчатский: КамГУ им. В. Беринга, 2009. С. 101-108.
Феофилактов С.О., Нуждаев И.А. Особенности глубинного строения Нижне-Кошелевского геотермального месторождения на основе сопоставления данных микросейсмического зондирования и гравиметрии // Материалы X Региональной молодежной научной конференции, Петропавловск-Камчатский, 12-13 апреля 2011 г. Петропавловск-Камчатский: КамГУ им. В. Беринга, 2011. С. 181-194.

Abrenica A., Harijoko A., Kusumah Y.I., Bogie I. Characteristics of Hydrothermal Alteration in Part of the Northern Vapor-Dominated reservoir of the Wayang Windu Geothermal Field, West Java // Proceedings World Geothermal Congress 2010. Bali, Indonesia, 25-30 April, 2010. 5 p.

Allis $R$. Insights on the Formation of Vapor-Dominated Geothermal Systems // Proceedings World Geothermal Congress 2000. Kyushu-Tohoku, Japan, May 28-June 10, 2000. P. 2489-2496.

Bellani S., Brogi A., Lazzarotto A. et al. Heat flow, deep temperatures and extensional structures in the Larderello Geothermal Field (Italy): constrains on geothermal fluid flow // Journal of Volcanology and Geothermal Research. 2004. V. 132. P. 15-29.

Benz H.M., Zandt G., Oppenheimer D.H. Lithospheric structure of northern California determined from teleseismic images of the upper mantle // Journal of Geophysical Research. 1992. V. 97. P. 4791-4807.

Bergfeld D., Goff F., Janik C.J. Carbon isotope systematics and $\mathrm{CO}_{2}$ source in the Geysers-Clear Lake region, northern California, USA // Geothermics. 2001. V. 30. P. 303-331.

Bergfeld D., Janik C.J., Goff F. $\mathrm{CO}_{2}$ degassing from pointsource locations in the Geysers-Clear Lake geothermal region of Northern California // EOS Transactions AGU. 1997. V. 78.328 p.

Bernabini M., Bertini G., Cameli G.M. et al. Gravity interpretation of Mt. Amiata geothermal area (Central Italy) // Proc. World Geothermal Congress, Florence, 18-31 May 1995. Florence. 1995. V. 2. P. 859-862.

Bertani R. Geothermal Power Generation in the World 2005-2010 Update Report // Proceedings World Geothermal Congress 2010. Bali, Indonesia, 25-30 April, 2010. $41 \mathrm{p}$.

Bertani R., Bertini G., Cappetti G. et al. An Update of the Larderello-Travale/Radiocondoli Deep Geothermal System // Proceedings World Geothermal Congress 2005. Antalya, Turkey, 24-29 April, 2005. 7 p.

Bogie I., Kusumah Y.I., Wisnandary M.C. Overview of the Wayang Windu geothermal field, West Java, Indonesia // Geothermics. 2008. V. 37. P. 347-365.

Capetti G., Romagnoli P., Sabatelli F. Geothermal Power Generation in Italy 2005-2009 Update report // Proceedings World Geothermal Congress 2010. Bali, Indonesia, 24-30 April, 2010. 8 p.

Casim M., Ciuffi S., Fiordelisi A., Mazotti A. 3D Seismic Surveys and Deep Target Detection in the Larderello-Travale Geothermal Field (Italy) // Proceedings World Geothermal Congress 2010. Bali, Indonesia, 25-30 April, 2010. 7 p.

Castillo D.A., Ellsworth W.L. Seismotectonics of the San Andreas fault system between Point Arena and Cape Mendocino in northern California: implications for the development and evolution of a young transform // Journal of Geophysical Research. 1993. V. 98. P. 6543-6560. 
Darma S., Harsoprayitno S., Setiawan B. et al. Geothermal Energey Update: Geothermal Energy Development and Utilization in Indonesia // Proceedings World Geothermal Congress 2010. Bali, Indonesia, 25-30 April, 2010. 13 p.

Dickinson W.R., Snyder W.S. Geometry of triple junctions related to San Andreas transform // Journal of Geophysical Research. 1979. V. 84. P. 561-572.

Dwikorianto T., Abidin Z., Kamah Y. et al. Tracer Injection Evalution in Kamojang Geothermal Field, West Java, Indonesia // Proceedings World Geothermal Congress 2005. Antalya, Turkey, 24-29 April, 2005. 8 p.

Fujimoto K., Takahashi M., Doi N., Kato O. High permeabilities of Quaternary granites in Japan and its implications for mass and heat transfer in a magmatic-hydrothermal system // Water-Rock Interaction. Japan, 1998. V. 9. P. 227-230.

Futa K., Hedge C.E., Hearn B.C., Donnely-Nolan J.M. Strontium isotopes in the Clear Lake volcanics // Research in the Geysers-Clear Lake Geothermal Area, Northern California. US Geological Survey Professional Paper. 1981. V. 1141. 259 p.

Geological Survey of Japan, Geology and mineral resources of Japan. Kawasaki: Geol. Surv. Japan, 1960. 304 p.

Gianelli G., Manzella A., Puxeddu M. Crustel models of the geothermal areas of southern Tuscany (Italy) // Tectonophysics. 1997. V. 281. P. 221-239.

Gianelli G., Puxeddu M., Squarci P. Structural setting of the Larderello-Travale geothermal region // Mem. Soc. Geol. Ital. 1978. V. 19. P. 469-476.

Hadi J., Harrison C., Keller J., Rejeki S. Overview of Daradjat Reservoir Characterization, A Volcanic Hosted Reservoir // Proceedings World Geothermal Congress, Antalya, Turkey 2005. $11 \mathrm{p}$.

Hanano M., Sakagawa $Y$. Lateral steam flow revealed by a pressure build-up test at the Matsukawa vapor-dominated geothermal field, Japan // Geothermics. 1990. V. 19. № 1. P. 29-42.

Hedenquist J.W., Izawa E., Arribas A., White N.C. Epithermal gold deposits: Styles, characteristics and exploration // Resource Geology. 1996. Special Publication. № 1.18 p.

Jennings C.W. Preliminary fault activity map of California // California Department of Mines and Geology Open-File Report. 1992. № 92-03. 22 p.

Lachenbruch A.H., Sass J.H. Heat flow and energetics of the San Andreas fault zone // Journal of Geophysical Research. 1980. V. 85. P. 6185-6222.

Lund J.W., Gawell K., Boyd T.L., Jennejohn D. The United States Country Update 2010 // Proceedings World Geothermal Congress 2010. Bali, Indonesia, 25-30 April 2010. 18 p.

McLaughlin R.J., Moore D.M., Sorg D.H., McKee E.H. Multiple episodes of the hydrothermal circulation, thermal metamorphism, and magma injection beneath the Geysers steam field, California // Geol. Soc. Amer. 1983. V. 15. P. 417.

Moore J.N., Adams M.C., Anderson A.J. The fluid-inclusion and mineralogic record of the transition from liquid- to vapor-dominated conditions in the Geysers geothermal system, California // Econ. Geology. 2000. V. 95. P. 1753-1773.

Moore J.N., Gunderson R.P. Fluid-inclusion and isotopic systematics of an evolving magmatic-hydrothermal system // Geoch. Cosmoch. Acta. 1995. V. 59. P. 3887-3907.

Norton D.L., Hulen J.B. Preliminary numerical analysis of the magma-hydrothermal history of the Geysers geother- mal system, California, USA // Geothermics. 2001. V. 30. P. 211-234.

Pandeli E., Gianelli G., Puxeddu M. Elter F.M. The Paleozoic Basement of the Northern Apennines: stratigraphy, tectono-metamorphic evolution and alpine hydrothermal processes // Mem. Soc. Geol. Ital. 1994. V. 48. P. 627-654.

Pramono B., Colombo D. Microearthquke Characteristics in Daradjat Geothermal Field, Indonesia // Proceedings World Geothermal Congress 2005. Antalya, Turkey, 24-29 April, 2005. 6 p.

Pruess $K$. A quantitative model of vapor-dominated geothermal reservoirs as heat pipes in fractured porous rock // Trans. Geotherm. Resourc. Counc. 1985. V. 9 (II). P. 353-361.

Rejeki S., Hadi J., Suhayati I. Porosity Study for Detail Reservoir Characterization in Darajat Geothermal Field, West Java, Indonesia // Proceedings World Geothermal Congress 2005. Antalya, Turkey, 24-29 April, 2005. 7 p.

Rejeki S., Rohrs D., Nordquist G., Fitriyanto A. Geologic Conceptual Model Update of the Darajat Geothermal Field, Indonesia // Proceedings World Geothermal Congress 2010. Bali, Indonesia, 25-30 April, 2010. 12 p.

Reutter K.J., Giese P., Closs H. Lithospheric split in descending plate: observations from the northern Apennines // Tectonophysics. 1980. V. 64. P. 1-11.

Reyes A.G. Petrology of Philippine geothermal systems and the application of alteration mineralogy to their assessment // Journal of Volcanological and Geothermal Research. 1990. V. 43. P. 279-309.

Rychagov S.N. Hydrothermal-Magmatic Systems as the Basic Source for Energetic and Mineral Resources of Recent Volcanism Areas // Proceedings World Geothermal Congress 2005. Antalya, Turkey, 24-29 April, 2005. 11 p.

Rychagov S.N., Belousov V.I., Kotenko T.A., Kotenko L.V. Gas-Hydrothermal System of the Ebeko Volcano (Paramushir Island) - Zone of Ascending Fluid Flow in the Structure of the North-Kuril Geothermal Deposit // Proceedings World Geothermal Congress 2010. Bali, Indonesia, 25-29 April, 2010. 12 p.

Sekine $Y$. Some notes on the metallogenic epochs and Provinces of Japan // Earth Science. 1956. № 29. P. 9-19.

Shigeno $H$. Evolution history of the Kakkonda magma-hydrothermal system, Japan, estimated through simplifiedmodel numerical simulations // Proc. $25^{\text {th }}$ Workshop on geothermal reservoir engineering 2000. USA: Standford University, 2000. P. 135-142.

Sofyan Y., Daud Y., Kamah Y., Ehara S. Sustainable Geothermal Utilization Deduced from Mass Balance Estimation - A Case Study of Kamojang Geothermal Field, Indonesia // Proceedings World Geothermal Congress 2010. Bali, Indonesia, 25-30 April 2010. 6 p.

Stimac J.A. Evolution of the silicic magmatic system at Clear Lake, California from 0.65 to $0.30 \mathrm{Ma} / / \mathrm{PhD}$ dissertation: Queens University, Kingston, Ontario, Canada. 1991. 399 p.

Stimac J.A. Origin and significance of high-grade metamorphic xenoliths, Clear Lake, California // Active Geothermal Systems and Gold-Mercury Deposits in the Sonoma-Clear Lake Volcanics Fields, California. Society of Economic Geologists Guidebook Series. 1993. V. 16. P. 171-189.

Stimac J., Baroek M., Suminar A., Sagala B. Integration of Surface and Well Data tp Determine Structural Controls on Permeability at Salak (Awibengkok), Indonesia // Proceed- 
ings World Geothermal Congress 2010. Bali, Indonesia, 25-30 April 2010. 7 p.

Stimac J.A., Goff F., Wohletz K. Thermal modeling of the Clear Lake magmatic-hydrothermal system, California, USA // Geothermics. 2001. V. 30. P. 349-390.

Sugino H., Akeno T. Country Update for Japan // Proceedings World Geothermal Congress 2010. Bali, Indonesia, 24-30 April, 2010. 7 p.

Suhadolc P., Panza G.F. The European-African collision and its effects on the lithosphere-astenosphere system // Tectonophysics. 1988. V. 146. P. 59-66.

Sumintadireja P., Sudarman S., Mizinaga H., Ushijima K. Mise-A-La-Masse and Gravity Data Surveys at the Kamodjang Geothermal Field // Proceedings World Geothermal Congress 2000. Kuushu-Tohoku, Japan, May 28-June 10, 2000. P. 1777-1784.

Tamanyu $S$. Alternative geothermal heat sources besides the youngest volcanism related magma chamber - Examples in the Hohi and Sengan geothermal areas in Japan // Geothermal Resources Council Transactions. 1991. V. 15. P. 47-51.

Tamanyu S., Fujimoto K. Hydrothermal and Heat Source Model for the Kakkonda Geothermal Field, Japan // Proceedings World Geothermal Congress 2005. Antalya, Turkey, 24-29 April, 2005. 10 p.
Tosha T., Sugihara M., Nishi Y. Revised hypocenter solutions for microearthquakes in the Kakkonda geothermal field, Japan // Geothermics. 1998. V. 27. P. 553-571.

Uchida T., Akaku K., Sasaki M., Kamenosono H. et al. Recent progress of NEDOs "Deep-seated geothermal resources survey" project // Geothermal Resources Council Transactions. 1996. V. 20. P. 643-648.

Utami P. Characteristics of the Kamodjang Geothermal Reservoir (West Java) as revealed by its hydrothermal alteration mineralogy // Proceedings World Geothermal Congress 2000. Kyushu-Tohoku, Japan, May 28-June 10, 2000. P. $1921-1926$.

Verdoya M., Pasquale V., Chiozzi P. Thermo-mecanical evolution and rheology of the northern sector of the Tyrrhenian-Apennines system // Journal of Volcanology and Geothermal Research. 2005. V. 148. P. 20-30.

Villa I.M., Puxeddu M. Geochronology of the Larderello geothermal field: new data and the closure temperature issue // Contrib. Mineral. Petrol. 1994. V. 315. P. 415-426.

Walters M., Combs J. Heat flow regime in the Geysers-Clear Lake region of northern California, USA // Transactions Geothermal Resources Council. 1989. V. 13. P. 491-502.

Walters M.A., Haizlip J.R., Sternfeld J.N. et al. A vapordominated reservoir exceeding $600^{\circ} \mathrm{F}$ at the Geysers, Sonoma County, California // Monograph on the Geysers geothermal field. Geotherm. Resourc. Counc. Spec. Rept. 1992. V. 17. P. 45-53.

\title{
Giant Gas-Rich Hydrothermal Systems and their Role in the Generation of Vapor-Dominated Geothermal Fields and Ore Mineralization
}

\author{
S. N. Rychagov \\ Institute of Volcanology and Seismology, Far East Branch, Russian Academy of Sciences, \\ Petropavlovsk-Kamchatskii, 683006 Russia \\ e-mail:rychsn@kscnet.ru \\ Received January 21, 2013
}

\begin{abstract}
This paper caracterizes certain unique geological structures on the earth, viz., giant gas-rich hydrothermal systems with major vapor-dominated geothermal fields that are generated beneath them during the present phase of evolution. A review of the relevant literature and materials of our own research are used to show that such systems are formed in zones of deep-seated faults at junctions of oceanic and continental plates, in structures of volcanic island arcs, and in areas of crustal tectono-magmatic activity. The systems extend throughout the crustal thickness and possess enormous geothermal and ore potentials. It was found that in these systems the ascending high-temperature gas-water fluid, as well as all types of mixed waters, and new mineral compounds in the hypergenesis zone of geothermal anomalies, all take part in the transport, accumulation, and rearrangement of complex compounds of many metals ( $\mathrm{Fe}, \mathrm{Al}, \mathrm{Ti}, \mathrm{Au}, \mathrm{Ag}, \mathrm{Hg}, \mathrm{As}, \mathrm{Sb}$, and others). It was inferred that gas-rich hydrothermal systems and the vapor-dominated geothermal fields that are formed beneath them reflect the conditions for the generation of mesothermal and epithermal gold and complex ores and of $\mathrm{Au}-\mathrm{Ag}-\mathrm{Cu}-\mathrm{Mo}$ porphyric deposits.
\end{abstract}

